\title{
Identifying convective transport of carbon monoxide by comparing remotely sensed observations from TES with cloud modeling simulations
}

\author{
J. J. Halland ${ }^{1}$, H. E. Fuelberg ${ }^{1}$, K. E. Pickering ${ }^{2}$, and M. Luo ${ }^{3}$ \\ ${ }^{1}$ Department of Meteorology, Florida State University, Tallahassee, Florida, USA \\ ${ }^{2}$ NASA Goddard Space Flight Center, Greenbelt, Maryland, USA \\ ${ }^{3}$ Jet Propulsion Laboratory, Pasadena, California, USA
}

Received: 18 September 2008 - Published in Atmos. Chem. Phys. Discuss.: 14 November 2008

Revised: 11 June 2009 - Accepted: 12 June 2009 - Published: 3 July 2009

\begin{abstract}
Understanding the mechanisms that transport pollutants from the surface to the free atmosphere is important for determining the atmosphere's chemical composition. This study quantifies the vertical transport of tropospheric carbon monoxide (CO) by deep mesoscale convective systems and assesses the ability of the satellite-borne Tropospheric Emission Spectrometer (TES) to detect the resulting enhanced $\mathrm{CO}$ in the upper atmosphere. A squall line that is similar to one occurring during NASA's INTEX-B mission is simulated using a typical environmental wind shear profile and the 2-D Goddard Cumulus Ensemble model. The simulation provides post-convection $\mathrm{CO}$ profiles. The structure of the simulated squall line is examined, and its vertical transport of CO is quantified. Then, TES' ability to resolve the convectively modified $\mathrm{CO}$ distribution is documented using a "clear-sky" retrieval scheme. Results show that the simulated squall line transports the greatest mass of $\mathrm{CO}$ in the upper levels, with a value of $96 t$ upward and $67 t$ downward at $300 \mathrm{hPa}$. Results indicate that TES has sufficient sensitivity to resolve convectively lofted $\mathrm{CO}$, as long as the retrieval scene is cloud-free. TES swaths located immediately downwind of squall lines have the greatest chance of sensing convective transport because the impact of clouds on retrieval quality becomes less. A note of caution is to always analyze TES-derived CO data (or data from any satellite sensor) together with the retrieval averaging kernels that describe the information content of the retrieval.
\end{abstract}

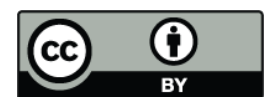

Correspondence to: H. E. Fuelberg (fuelberg@met.fsu.edu)

\section{Introduction}

Anthropogenic pollution impacts many of the Earth's natural processes. Carbon monoxide $(\mathrm{CO})$ is a byproduct of the incomplete combustion of carbon fuels and the oxidation of methane and non-methane hydrocarbons (Jacob, 1999). With a lifetime of approximately one month, $\mathrm{CO}$ is an excellent tracer of pollution sources and pathways. $\mathrm{CO}$ also is a precursor to tropospheric ozone $\left(\mathrm{O}_{3}\right)$. CO concentrations near the surface in the United States typically are $>200 \mathrm{ppbv}$ in urban areas, $100-200 \mathrm{ppbv}$ in rural areas, and $<100 \mathrm{ppbv}$ in remote areas (e.g., Jacob, 1999).

In the presence of nitrogen oxides $\left(\mathrm{NO}_{\mathrm{x}}\right)$ and water vapor, the photochemical oxidation of $\mathrm{CO}$ produces tropospheric $\mathrm{O}_{3}$ (Beer, 2006). $\mathrm{O}_{3}$ then can create hydroxyl radicals $(\mathrm{OH})$ by photolysis in the presence of water vapor, and $\mathrm{OH}$ is a major oxidant that removes pollutants such as methane and $\mathrm{CO}$. Boundary layer pollutants that are rapidly transported to the free troposphere (FT) have increased lifetimes due to diminished loss mechanisms such as dry deposition, wetscavenging by precipitation, and $\mathrm{OH}$ radicals (Park et al., 2001). In the upper troposphere where $\mathrm{O}_{3}$ acts as a greenhouse gas, enhanced $\mathrm{O}_{3}$ production in regions downwind of convection (Chatfield and Delany, 1990; Pickering et al., 1990; Park et al., 2001), along with the longer lifetimes of $\mathrm{O}_{3}$ and its precursors, directly influence the Earth's radiation balance. Transport to the upper troposphere has important implications for climate and the intercontinental transport of pollution which affects air quality at distant locations. The longer lifetime and faster transport imply a larger scale impact. Thus, identifying the concentrations and distributions of $\mathrm{CO}$ at different altitudes is vital to effectively calculating

Published by Copernicus Publications on behalf of the European Geosciences Union. 


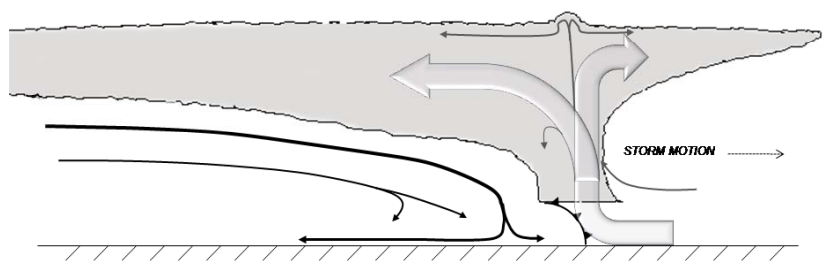

Fig. 1. Schematic of the flow regimes in a mesoscale convective system (adapted from Houze et al., 1989). Large hollow arrows identify the ascending front to rear inflow (left) and core updraft transporting air to the cloud top and forward anvil (right). Black arrows represent the rear inflow jet supporting the cold pool generation directly below the core updraft.

$\mathrm{O}_{3}$ production and making better forecasts of the evolving radiation balance using climate models.

Pollutants generated at the surface can be transported vertically over depths ranging from tens to thousands of meters. The key factor determining the height of vertical transport is the type of meteorological system that is responsible. These systems range from synoptic scale cyclones, to mesoscale convective systems (MCS), to dry-convection and turbulence (Pickering et al., 2003). Deep convection is one of the most efficient transporters of boundary layer air to the FT (Park et al., 2001; Dickerson et al., 1987). It is estimated that the mass of the atmospheric boundary layer (ABL) is vented $\sim 90$ times annually by clouds and cloud systems (Cotton et al., 1995). Calculations for the central United States suggest that nearly fifty-percent of ABL CO is transported to the FT by deep convection during summer (Thompson et al., 1994). Thus, estimating vertical transport by sub-grid scale mechanisms in chemical transport models is crucial for representing distributions of $\mathrm{CO}, \mathrm{O}_{3}$, and other species.

This study investigates the vertical transport of $\mathrm{CO}$ by mesoscale convective systems (MCSs). An MCS is a region of multi-cellular convection with a contiguous area of precipitation that spans $100 \mathrm{~km}$ or more in at least one horizontal direction (Glickman, 2000). The squall line is one prominent type of MCS, identified by its larger length-towidth ratio. We investigate a typical squall line that is similar to one occurring during NASA's INTEX-B field project (Singh et al., 2009). Squall lines depend on environmental vertical wind shear to balance the horizontal vorticity generated by the convection's buoyant updraft, its rear-inflow jet (RIJ), and cold-pool at the surface (Rotunno et al., 1987; Weisman et al., 1988; Weisman and Rotunno, 2004). Dominant features of a squall line (Fig. 1) are strong updrafts at its leading edge and the ascending front-to-rear inflow that begins near the surface. Their magnitudes control how deep the convection can penetrate, and thus to what altitude surface pollutants are transported. Although a typical single-cell thunderstorm produces a maximum updraft of 8 to $15 \mathrm{~m} \mathrm{~s}^{-1}$, deep multi-cellular convection often generates updrafts greater than $35 \mathrm{~m} \mathrm{~s}^{-1}$ (Cotton et al., 1995). Pollutants transported in the convective updraft then can disperse from the cloud by detrainment along the core-updraft, the cloud anvil, and the edges of the cloud (Thompson et al., 1997). As a result, the ascending polluted air becomes diluted as it exits the cloud. Many squall lines also contain a descending rear inflow jet that is located behind the convective core in the middle and lower troposphere (Fig. 1).

The 1985 PRESTORM project provided some of the first direct measurements in the anvils of convective storms. Dickerson et al. (1987) found that the anvil contained 64\% $\mathrm{ABL}$ air and $36 \%$ upper tropospheric air after including the effects of entrainment. Pickering et al. (1989) identified enhanced layers of $\mathrm{CO}$ due to cumulonimbus venting over $500 \mathrm{~km}$ upwind. Pickering et al. (1990) related significant $\mathrm{O}_{3}$ enhancements to convective injection of precursors into the upper troposphere (UT). Their research identified a major source of UT pollution that then can be rapidly transported horizontally to other regions.

Recent field projects also have examined mechanisms producing long-range chemical transport (Singh et al., 2006, 2009). A comparison of transport processes in Northeast China and the Northeast United States found that different mechanisms were involved (Dickerson et al., 2007). Dry convection was the prominent pollution transporter over China during the spring season. However in the United States, deep, moist convection was the dominant transporter. Although both types of convection vented PBL air to the FT, the lack of wet-deposition in dry convection was speculated to be the main cause of enhanced pollution-venting over China (Dickerson et al., 2007).

The boundary layer venting of pollution by both fairweather cumulus and deep convection has been successfully modeled for over two decades (Niewiadomski, 1986; Tremblay and Leighton, 1986; Pickering et al., 1995). Simulations of towering cumulus (Niewiadomski, 1986) revealed pollutant reduction percentages and vertical transport ratios (volume of sub-cloud air transported through the cloud base relative to the total volume of air below the cloud layer) of 15 and 23 percent, respectively. These values are similar to those found previously for cumulus outflow (Isaac et al., 1983). In a study of $\mathrm{O}_{3}$ production downstream of deep convection over Brazil, nearly all of the air parcels in the anvil originated in the boundary layer (Thompson et al., 1997). Based on back trajectories, Thompson et al. found that many parcels were transported from $0.3 \mathrm{~km}$ to $15 \mathrm{~km}$ AGL in less than $30 \mathrm{~min}$. The vertical transport of $\mathrm{CO}$ by deep convection embedded in the warm-conveyor belts (WCB) of middle latitude cyclones was studied by Kiley and Fuelberg (2006). They found that the dominant vertical forcing mechanism was the Laplacian of latent heat release which is large in areas of deep convection. Deep convection in weak synoptic cyclones proved especially critical for the development of WCB-like transport. Other studies that have modeled or directly sampled pollution transport by both synoptic and mesoscale weather systems include Pickering et al. (1989), 
Park et al. (2001), Hannan et al. (2003), and Dickerson et al. (2007).

Since vertical transport occurs on a global scale, satellite remote sensing is the only way that it can be documented. NASA launched the Tropospheric Emission Spectrometer (TES) instrument onboard the Aura platform in 2004. TES can make vertical profile retrievals of several atmospheric variables including temperature, water vapor, $\mathrm{CO}$, and ozone. Since only nadir measurements are taken global coverage of all variables requires approximately ten days (Beer, 2006). We use TES derived CO profiles in this study, and additional details are given in Sect. 2.

Our first objective is to quantify the vertical transport of lower tropospheric air by a squall line. The squall line is simulated using the 2-D Goddard Cumulus Ensemble (GCE) model which provides post-convection $\mathrm{CO}$ profiles. Comparisons with pre-convective profiles describe the vertical transport. The second objective is to gain insight into TES' ability to detect $\mathrm{CO}$ convective transport. This is achieved by inputting the pre- and post-convection simulated $\mathrm{CO}$ profiles to the TES retrieval algorithm to obtain synthetic retrievals. Finally, we examine observed TES retrievals located downwind of the squall line.

\section{Data and methodology}

We selected a squall line occurring on 13 March 2006 because it is typical of the many lines that occur each year and because it occurred during NASA's INTEX-B field project (Singh et al., 2009) when special high resolution TES retrievals were available. Figure 2 a shows the radar-derived location of the squall line near 08:00 UTC, while Fig. 2b shows a GOES infrared image of the event. The squall line is oriented northeast to southwest, extending from the Great Lakes to northeastern Texas. Its deep convective core contains reflectivities of $45-55 \mathrm{dBZ}$, while stratiform areas have values $<30 \mathrm{dBZ}$.

\subsection{TES Instrument and CO profile retrievals}

The Tropospheric Emission Spectrometer (TES) is housed on the Earth Observing System Aura platform (Beer, 2006). Aura's orbit is near-polar, sun-synchronous at an altitude of $705 \mathrm{~km}$, with an ascending equatorial crossing near 13:35 local solar time. TES is a nadir viewing infrared Fourier transform spectrometer that samples the atmospheric absorption/emission spectra of several gases (Beer, 2006; Bowman, 2006). TES functions in two primary observation modes, the global survey mode (GS) and the step and stare mode (SS). The GS mode consists of 16 orbits with a successive nadir sampling distance of $182 \mathrm{~km}$ along the track, while the SS mode spans 45 degrees latitude and consists of 150 nadir observations at a separation of $40 \mathrm{~km}$ along the track over $5 \times 8 \mathrm{~km}$ horizontal footprints. TES normally operates

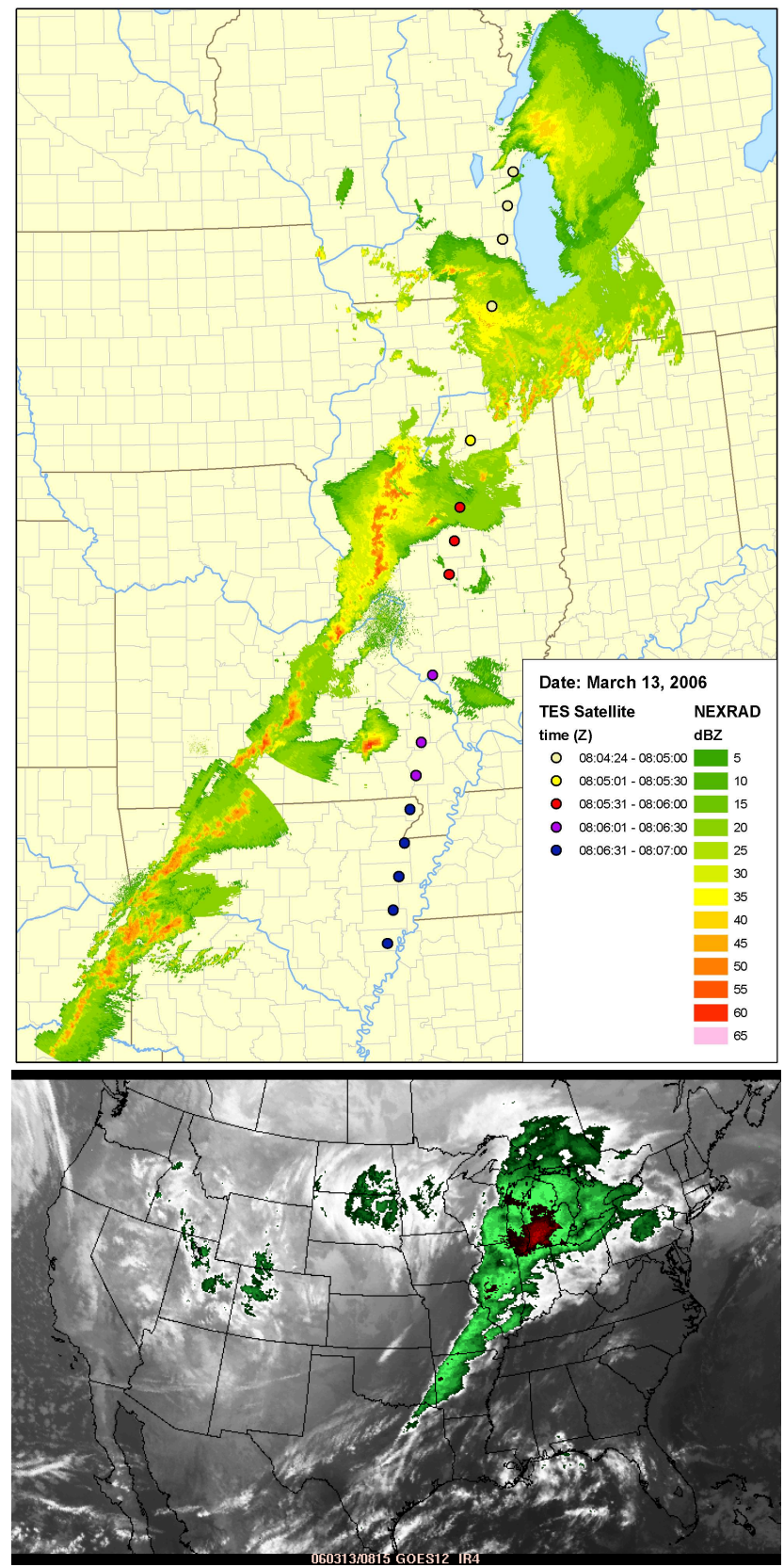

Fig. 2. (a) Radar reflectivity of the squall line (dBZ) at 08:04 UTC 13 March 2006, along with TES retrieval locations. The reflectivities are a composite from individual National Weather Service WSR-88D (NEXRAD) radars in the area. TES moves from NE (location 0 ) to SW (location 15), crossing the squall line near Lincoln, IL. The TES footprints are color-coded to show the time of each retrieval. The averaging kernel profile at site 14 (second from the south) was used to make our synthetic TES retrievals. Since the GCE is run in the $\mathrm{x}-\mathrm{z}$ plane, its axis along the length of the squall line is arbitrary. (b) GOES-12 enhanced infrared satellite image for 08:15 UTC 13 March 2006. 
in a one-day-on followed by a one-day-off GS mode. However, during a science campaign such as INTEX-B, TES can schedule special SS observations during the "off days". Thus, our research benefitted from the high resolution SS retrievals.

The parameter degrees of freedom for signal (DOFS) "describes the number of useful independent quantities there are in a measurement, and hence is a measure of information" (Rodgers, 2000). TES' high spectral resolution of $0.1 \mathrm{~cm}^{-1}$ (nadir viewing) enables it to provide vertical $\mathrm{CO}$ profiles in the troposphere with 1-2 DOFs in the tropics to mid latitude regions (Luo et al., 2007a).

The TES retrieval algorithm is an optimal estimation method that minimizes the residual between the observed and modeled radiances (Rodgers, 2003; Bowman et al., 2006). The a priori constraints represented by the atmospheric species profiles and their uncertainties are explicitly applied. Unlike cloud-clearing and cloud-masking schemes utilized in other retrieval schemes, TES' cloud retrieval strategy assumes a layer of effective cloud with the spectral dependent extinctions and the layer pressure retrieved (Kulawik et al., 2006). In addition to these effective cloud data provided in the data files, the averaging kernels for the profile retrievals also are provided.

The averaging kernels and the a priori profiles provide useful information for understanding the retrieved profiles. A retrieved species profile is not the true atmospheric profile at a given location and time. The following equation approximates the relationship between the true profile, $x_{t}^{i}$, the a priori profile, $x_{t, \mathrm{TES}}^{i}$, and the retrieved profile (Rodgers, 2003, Luo et al., 2007a),

$\hat{x}_{t}^{i}=x_{t, \mathrm{TES}}^{i}+A_{t}^{i}\left(x_{t}^{i}-x_{t, \mathrm{TES}}^{i}\right)+\varepsilon_{t}^{i}$,

where $A_{t}^{i}$ is the averaging kernel matrix for the profile and $\varepsilon_{t}^{i}$ is the observational error due to instrument noise. In the ideal case, when the averaging kernel is a unit matrix, the retrieved profile equals the true profile. However, the remote sensing solutions are far from the ideal case, due to the lack of information in the observed spectral radiance on the species profiles and the limitations of the instrument characteristics and performances. We will show examples of the TES averaging kernel for $\mathrm{CO}$ retrievals in later sections. In the worst case, there is no information on atmospheric $\mathrm{CO}$ profiles from the nadir spectral measurements (very small averaging kernel values). The retrieved profile is then dominated by the a priori profile. An example of this case is the cloud. The TES observed spectra contain no information on the CO distribution within and below the clouds. The averaging kernels in this vertical portion are very small, and the retrieved $\mathrm{CO}$ values are dominated by the a priori profile. TES CO retrievals have been found to be consistent with those from MOPITT (Luo et al., 2007a) and within 15\% of aircraft data (Luo et al., 2007b; Lopez et al., 2008).

\subsection{Creating synthetic $\mathrm{CO}$ profiles}

Using Eq. (1), TES a priori and averaging kernel data on 13 March 2006 at $39^{\circ} \mathrm{N}$ were used to generate two sets of synthetic TES retrieved $\mathrm{CO}$ profiles. The first set of synthetic profiles used a $\mathrm{CO}$ profile from the GEOS-Chem chemical transport model (CTM, Bey et al., 2001a) as the true state profile prior to convective activity. The second set of retrievals, the post-convection true state profiles, was based on CO data output from the 2-D Goddard Cumulus Ensemble (GCE) cloud model (Tao and Simpson, 1993). Specifically, the GCE output was considered the true state of the atmosphere after $\mathrm{CO}$ had been transported by the storm system. Details of the GCE and GEOS-Chem model are given in Sect. 2.3 and 2.4, respectively.

The model-derived $\mathrm{CO}$ profiles were interpolated vertically to the TES pressure levels. Since the top of the model domain (troposphere) did not extend to the altitude at which TES makes retrievals, all pressure levels above the top of the model domain contain the TES retrievals as the true state values (Luo and Worden, 2007). Equation (1) then was used to generate the synthetic TES CO retrieval profiles. Comparisons between these simulated satellite retrieved profiles and the true profiles enable us to determine how well TES depicts the convective transport of $\mathrm{CO}$.

\subsection{Cloud-model}

The 2-D Goddard Cumulus Ensemble (GCE) (Tao and Simpson, 1993; Tao et al., 2003) is a convective cloud-resolving model that has been used to understand cloud interactions with each other, with the surrounding environment, and with trace gas distributions (Soong and Tao, 1980; Tao and Simpson, 1984; Scala et al., 1990; Pickering et al., 1991, 1992a, $\mathrm{b}, \mathrm{c})$. Its governing equations are non-hydrostatic since the horizontal and vertical scales of convection are similar. The model explicitly resolves gravity waves generated by the developing cloud in the x-z plane (Tao and Simpson, 1993) and contains microphysical processes that are sophisticated and sensitive to the dynamic processes resolved (Tao et al., 1991; Tao and Simpson, 1993), including the complete microphysics for all water phases (Soong and Ogura, 1980; Soong and Tao, 1980; Tao and Soong, 1986). An on-line chemical tracer advection capability has been added to the 2-D GCE model by Stenchikov et al. (1996).

The horizontal grid of the 2-D GCE consists of 514 points spanning $470 \mathrm{~km}$, with 33 vertical levels on a stretched grid whose spacing ranges from $220 \mathrm{~m}$ near the surface to $1050 \mathrm{~m}$ at the model's top of $25 \mathrm{~km}$. The model has open-type lateral boundary conditions, free-slip boundary conditions for model variables, and a $5 \mathrm{~km}$ Rayleigh relaxation (absorbing) layer at its top (Klemp and Wilhelmson, 1978; Tao and Simpson, 1993). All of our simulations used the model parameter settings listed in Table 1. A full description, including model 
Table 1. GCE model domain and parameter settings used in this study.

\begin{tabular}{ll}
\hline Parameter & Configuration \\
\hline $\begin{array}{l}\text { Physical Domain }(x-z) \\
\text { Horizontal Grid Spacing (stretched) }\end{array}$ & $514 \mathrm{~km} \times 25 \mathrm{~km}$ \\
Min & $750 \mathrm{~m}$ \\
Max & $1000 \mathrm{~m}$ \\
Vertical Grid Spacing (stretched) & \\
Min & $220 \mathrm{~m}$ \\
Max & $1050 \mathrm{~m}$ \\
Calculation Time Step & $2 \mathrm{~s}$ \\
Coordinate System Velocity & $0 \mathrm{~ms}-1$ \\
Uniform Initial Conditions & TRUE \\
Cold Pool Parameters & \\
Width & $8 \mathrm{~km}$ \\
Depth & $1.5 \mathrm{~km}$ \\
Cooling Rate & $7.0 \times 10^{-3} \mathrm{~K} \mathrm{~s}^{-1}$ \\
Boundary Conditions & \\
Top & $5 \mathrm{~km} \mathrm{Rayleigh} \mathrm{Relaxation} \mathrm{(absorbing)} \mathrm{layer}$ \\
Bottom & Free-slip \\
Lateral & Open (Klemp and Wilhelmson, 1978) \\
Microphysics & Kessler-type (Cloud water and rain) \\
Liquid Water & Three-category (Cloud ice, snow, graupel) \\
Ice & Lin et al. (1983) \\
& \\
&
\end{tabular}

equations and specific sensitivity studies, is provided in Tao and Simpson (1993) and Tao et al., (2003).

\subsection{Meteorological and chemical data}

Background $\mathrm{CO}$ describing the environment prior to the convection on 13 March 2006 was obtained from a run of the 3-D GEOS-Chem global chemical transport model (Bey et al., 2001a). GEOS-Chem uses the US anthropogenic emissions by the National Emission Inventory for 1999 (NEI99) from the US Environmental Protection Agency (EPA) (http://www.epa.gov/ttn/chief/trends/ procedures/neiproc_99.pdf), and the Asian anthropogenic inventory of Zhang et al. (2009) for 2006. For the rest of the world, the anthropogenic emissions are from the Global Emission Inventory Activity (GEIA), scaled to 1998 on the basis of national energy statistics as described by Bey et al. (2001b). Biomass burning emissions are from a monthly climatological inventory (Duncan et al., 2003).

GEOS-Chem version 7-04-09 uses assimilated meteorological fields from the Goddard Earth Observing SystemVersion 4 (GEOS-4) with a native resolution of $1^{\circ} \times 1.25^{\circ}$ (latitude $\times$ longitude) grid and 55 vertical levels (Bloom et al., 2005), processed on a $2^{\circ} \times 2.5^{\circ}$ grid with a reduced vertical spacing of 30 levels in a hybrid sigma-pressure coordinate system. Deep convection and shallow convection are parameterized separately in GEOS-4, following schemes described in Zhang and McFarlane (1995) and Hack (1994).

\subsection{Squall line simulations}

Mid-latitude squall lines have been simulated using twodimensional $(\mathrm{x}-\mathrm{z})$ cloud resolving models for over two decades (e.g., Ogura and Liou, 1980; Thorpe et al., 1982; Fovell and Ogura, 1988; Rotunno et al., 1987; Pickering et al., 1995). A 2-D model is justified since a squall line's structure varies mostly in the line normal direction (Fovell and Ogura, 1988) and since wind shear perpendicular to the line is what yields a steady convective cell (Rotunno et al., 1988).

Since the 2-D model does not consider variations along the length of the squall line, only a single thermodynamic sounding that represents the line as a whole is used as input. The sounding that we used for the GCE integrations (Fig. 3) has been employed in previous modeling studies of mid-latitude squall lines (Weisman and Klemp, 1982, 1984; Rotunno et al., 1988; Lericos et al., 2006) and was derived from soundings of typical squall line environments (Ogura and Liou, 1980; Bluestein and Jain, 1985; Fovell and Ogura, 1988). This sounding is similar to the pre-squall line thermodynamic environment over the US central plains on 13 March 2006 during NASA's INTEX-B field project (Singh et al., 2009).

Our pre-convective $\mathrm{CO}$ sounding was taken from the GEOS-Chem model near $41.61^{\circ} \mathrm{N}, 90.58^{\circ} \mathrm{W}$ at 00:00 UTC 13 March 2006 (Fig. 4). Once again, only a single sounding is needed since the $\mathrm{CO}$ profile is assumed to be similar along 


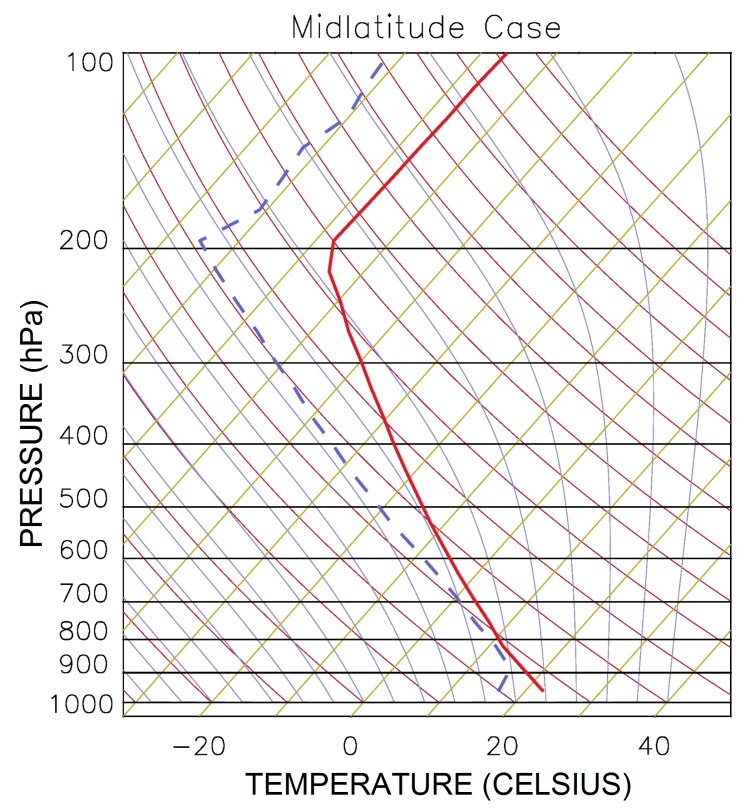

Fig. 3. Thermodynamic sounding of the pre-squall line environment used for the squall line simulation in this study. The solid red line denotes temperature, while the dashed blue line shows dew point temperature. The sounding is similar to that at Lincoln, IL at 00:00 UTC 13 March 2006 during INTEX-B.

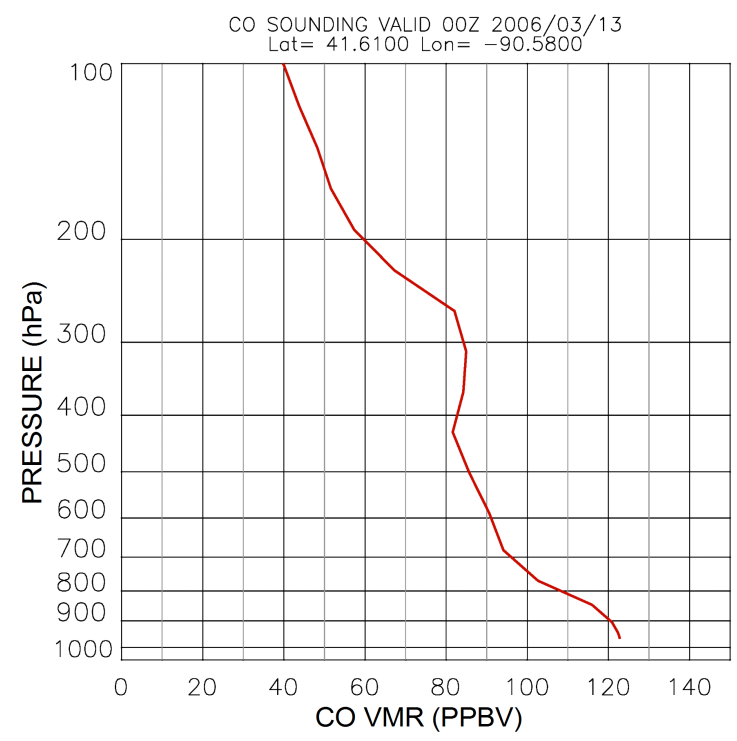

Fig. 4. CO profile (ppbv) from the GEOS-Chem model used as the background concentration in the GCE for the squall line simulation. The profile is valid at 00:00 UTC 13 March 2006 at $41.61^{\circ} \mathrm{N}$, $90.58^{\circ} \mathrm{W}$.

the length of the squall line. Since our goal was to investigate the basic transport effects of deep convection, using a CO profile slightly different from the one selected would not significantly affect the results that follow. The GEOS-4

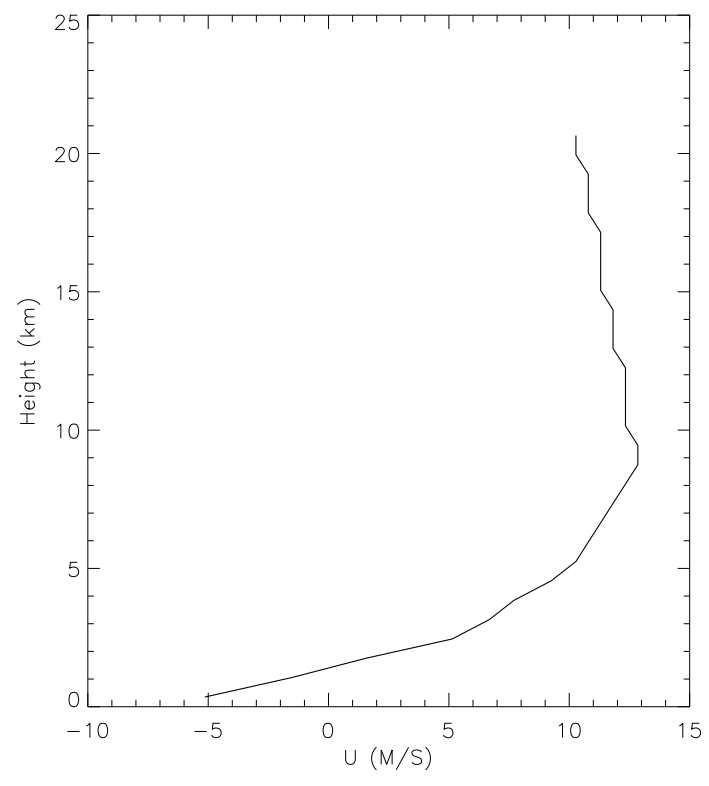

Fig. 5. The vertical wind profile used in the squall line simulation.

$300 \mathrm{hPa}$ cloud mass-flux field (not-shown) confirmed that no convection was located in the area at this time. Therefore, the CO profile represents nearly undisturbed background values prior to the arrival of the squall line. The CO profile was interpolated to 20 vertical levels and used as initial values in the GCE simulations. The grid spacing for the CO tracer (not the same as GCE resolution) consisted of $500 \mathrm{~m}$ layers between the surface and $2.5 \mathrm{~km}$ and then $1 \mathrm{~km}$ layers to $17.5 \mathrm{~km}$ with the concentration at $17.5 \mathrm{~km}$ used until the top of the model.

Low-level environmental wind shear is crucial for the development of steady convection (Thorpe et al., 1982; Fovell and Ogura, 1988; Rotunno et al., 1988; Lericos et al., 2006). Many previous squall line simulations have used shear-layer depths between 2.5 and $5.0 \mathrm{~km}$, with vertical wind shears ranging from 7 to $25 \mathrm{~m} \mathrm{~s}^{-1}$, respectively. Most then maintained uniform winds above the shear layer, with the exception of Thorpe et al. (1982). We tested several shear profiles that were adapted from those of Fovell and Ogura (1988) and Lericos et al. (2006). The profile in Fig. 5 most resembled conditions in our INTEX-B pre-storm environment since it contains a weak jet near $9 \mathrm{~km}$. The strongest shear of $17.5 \mathrm{~m} \mathrm{~s}^{-1}$ is between $350 \mathrm{~m}$ and $2450 \mathrm{~m}$, which gradually weakens to produce a peak wind speed of $12.5 \mathrm{~m} \mathrm{~s}^{-1}$ at $8950 \mathrm{~m}$. The shear then becomes negative, linearly decreasing $2.5 \mathrm{~m} \mathrm{~s}^{-1}$ between $8950 \mathrm{~m}$ and $20650 \mathrm{~m}$, the top of the sounding. The vertical transport of $\mathrm{CO}$ due to the squall line resulting from this wind profile is presented in later sections.

\subsection{TES retrievals}

We assumed that the GEOS-Chem CO profile used in our GCE simulations was the true atmospheric state of the preconvective environment (Sect. 2.4). A single TES CO 


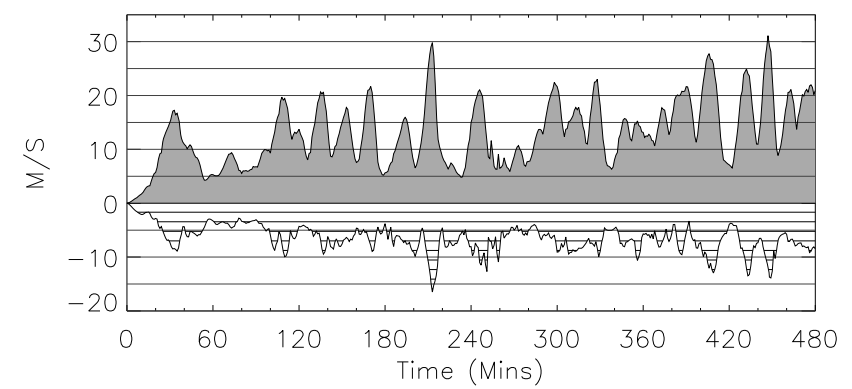

Fig. 6. Time-series of maximum updraft speed (W, positive values) and maximum downdraft speed (W, negative values) in $\mathrm{m} \mathrm{s}^{-1}$ during the entire 8-h squall line simulation period.

retrieval based on this profile was calculated using (1) and assigned to every horizontal grid point in the GCE model to determine how TES would depict the "pre-convection" CO concentrations. That is, this TES-depicted profile was identical along the entire axis of the $\mathrm{x}-\mathrm{z}$ simulation. We next took the GCE-derived CO profiles representing "post-convection" concentrations that did vary along the cross section and performed the same retrieval calculations. We used the averaging kernel from a clear-sky retrieval along the TES swath on 13 March 2006. Its location was the closest available to the GEOS-Chem derived pre-squall line CO profile.

\section{Results}

\subsection{Squall line structure}

We first establish the close agreement between our squall line simulation and those of previous studies who used similar wind shear profiles. A time-series of simulated maximum/minimum storm vertical motion (W) is shown in Fig. 6 . The storm first evolves through an "initial phase" in which the simulated cold pool initiates the convection (Rotunno et al., 1988). This initial phase is similar to Fig. 17 of Fovell and Ogura (1988). The magnitude of our initial updrafts is $\sim 18 \mathrm{~m} \mathrm{~s}^{-1}$ at $\sim 30 \mathrm{~min}$ into the simulation, before abruptly decreasing to $\sim 5 \mathrm{~m} \mathrm{~s}^{-1}$ at $\sim 60 \mathrm{~min}$. This marks the collapse of the initial cell, and the initiation of weak convection to the west (left) and east (right) (Fig. 7). Downdrafts from each cell then begin to intensify, leading to the formation of a single convective cell near $110 \mathrm{~min}$. The storm then evolves into a vigorous series of pulsating updrafts and downdrafts (Fig. 6). The storm's cyclic pattern of intensification and weakening corresponds to the initiation of new cells in the line and the decay of old cells (Figs. 7-9). Specifically, the cold pool due to the storm's downdraft surges rearward (to the left) where it forces new convection within a few kilometers of the main reflectivity core.
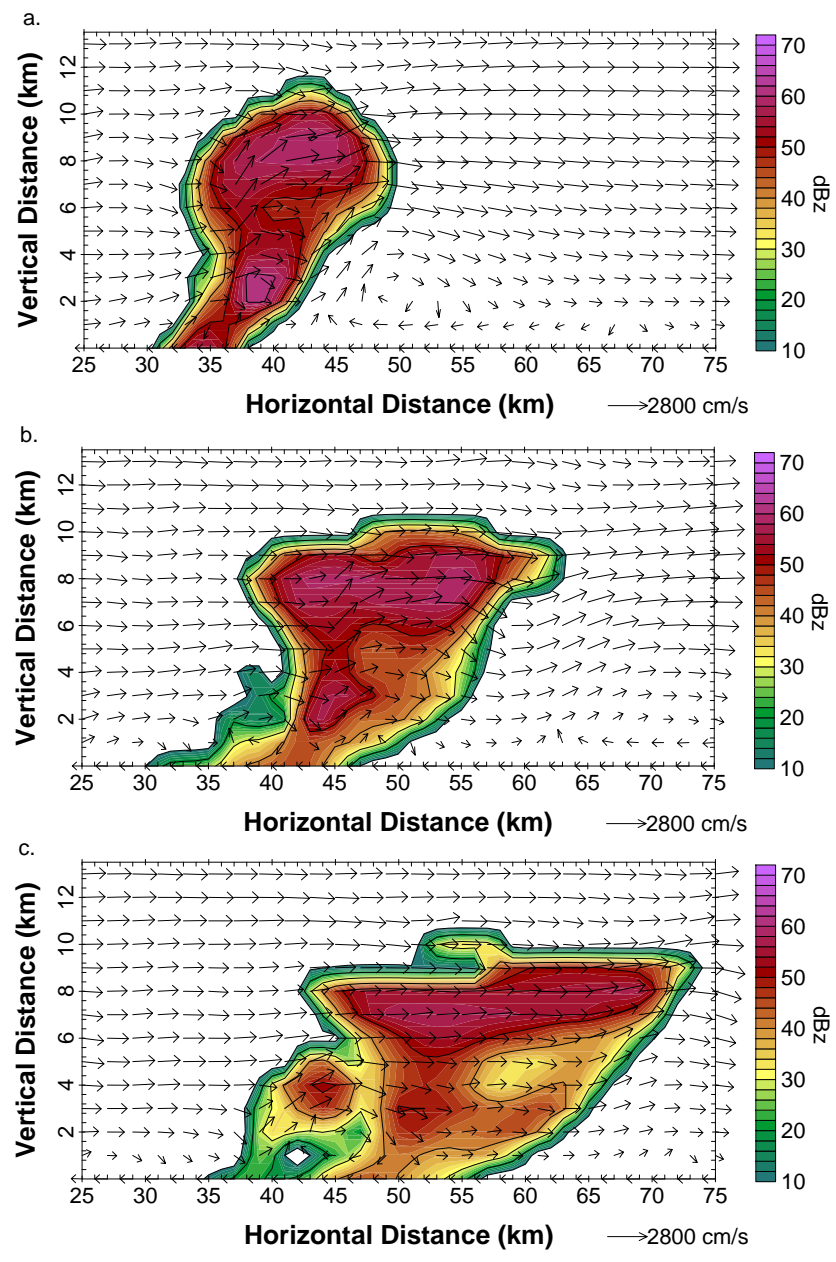

Fig. 7. U-W wind vectors and reflectivities (dBZ) at (a) $40 \mathrm{~min}$, (b) $50 \mathrm{~min}$, and (c) $60 \mathrm{~min}$ into the simulation. The longest arrow represents the maximum wind of (a) $27 \mathrm{~m} \mathrm{~s}^{-1}$, (b) $24 \mathrm{~m} \mathrm{~s}^{-1}$, and (c) $23 \mathrm{~m} \mathrm{~s}^{-1}$.

\subsection{CO transport characteristics}

We next describe the vertical distribution and mass flux of $\mathrm{CO}$ produced by the simulated squall line. Once the convection begins ( $\sim 40 \mathrm{~min}$, not shown), boundary layer $\mathrm{CO}$ is injected into the FT by the storm's strong updrafts. By $180 \mathrm{~min}$ (Fig. 10a), CO penetrates the stable region of the tropopause, with the lofted $\mathrm{CO}$ dispersed predominately eastward (toward the right) in the upper levels. As the $\mathrm{CO}$ reaches the tropopause, it begins to dilute as weaker concentrations of ambient $\mathrm{CO}$ are mixed into it.

The CO concentration of the dry mid-level air descending on the upshear (left) side of the storm (Figs. 4, 8) is smaller than at the surface. This air entering from the rear enhances the storm's downdraft and the mass of the cold pool, a feature also seen in previous studies (Ogura and Liou, 1980; Thorpe et al., 1982). This causes the cold pool to spread eastward 


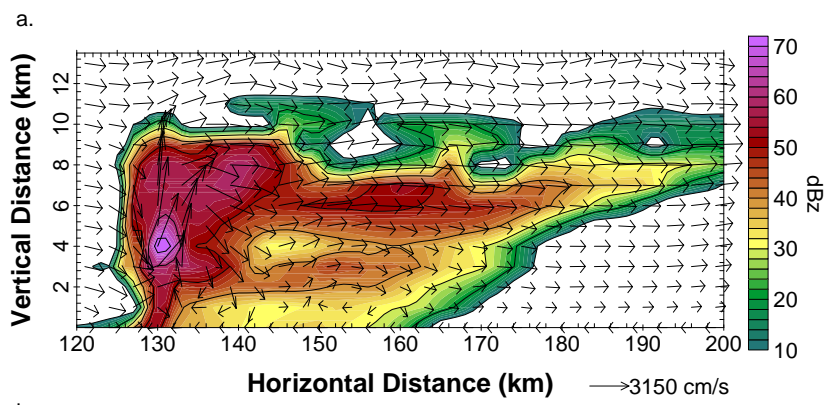

b.
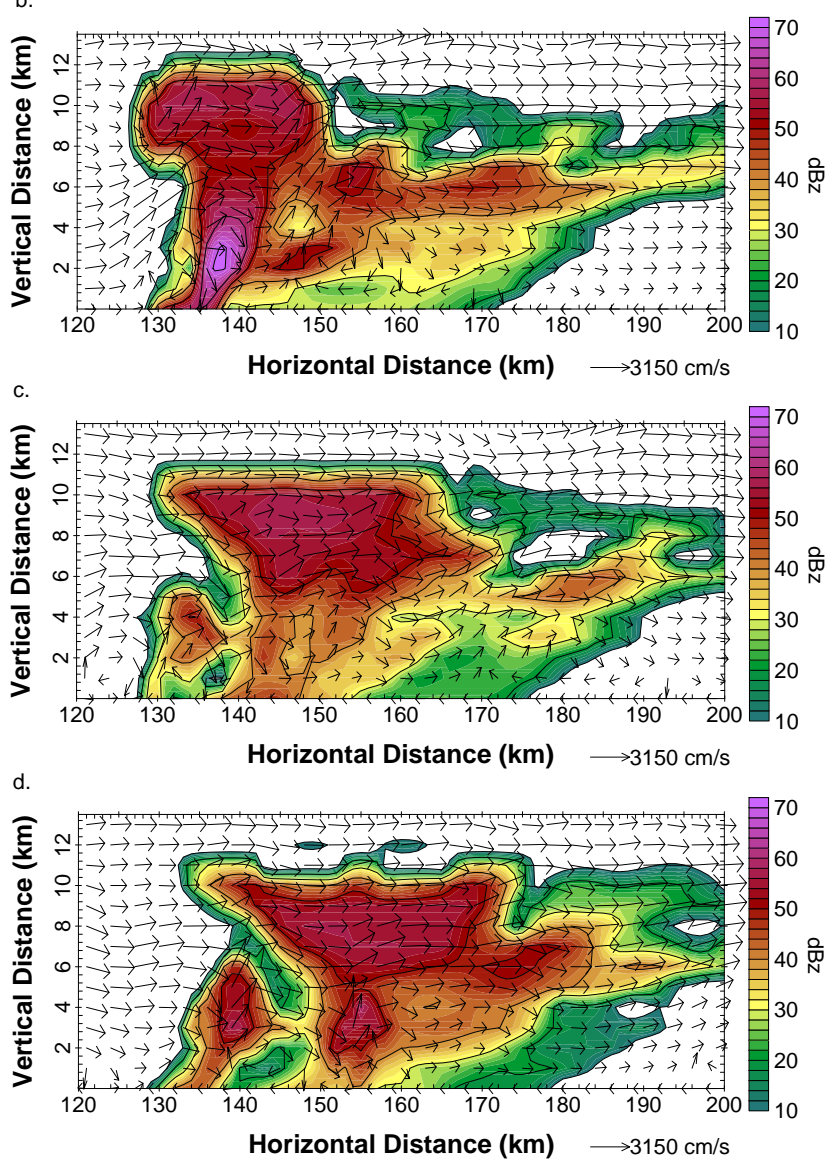

Fig. 8. Time series of U-W wind vectors and reflectivity (dBZ) at $10 \mathrm{~min}$ intervals from (a) $210 \mathrm{~min}$ to (d) $240 \mathrm{~min}$ into the simulation. The longest arrow represents $31 \mathrm{~m} \mathrm{~s}^{-1}$ wind speeds in (a), decreasing to $24 \mathrm{~m} \mathrm{~s}^{-1}$ in (d).

where it enhances the existing convection, and westward where new convection is initiated. The westward spread of the cold pool reduces $\mathrm{CO}$ in the boundary layer of the storm's wake (Fig. 10a-c).

The lofted $\mathrm{CO}$ is carried downwind by the relatively strong upper level winds centered near $9 \mathrm{~km}$ (Fig. 10). The downdrafts carrying upper level air back to the surface contain less CO than if the upper level winds had been nearly calm and the lofted $\mathrm{CO}$ had remained near the region of the incipient

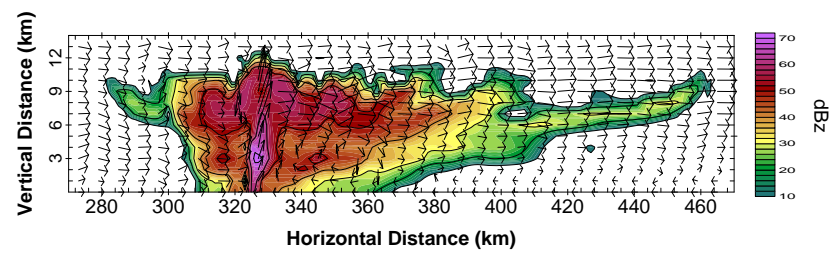

Fig. 9. Reflectivity pattern (dBZ) at the end of the $8 \mathrm{~h}$ simulation.

downdrafts. By the end of the simulation ( $480 \mathrm{~min}$ ), the CO plume aloft has developed a well defined forward component (Fig. 10c). Near the base of the updraft (i.e., near the surface) (Fig. 10b), there is a rather distinct demarcation between the downdraft air and the air ahead of the storm. This may be a result of downdrafts occurring in brief intense bursts. This variability in downdraft intensity may cause different levels of mixing near the surface, a possible mechanism for the $\mathrm{CO}$ signature in the wake of the storm. As is well known, the longer that the relatively clean downdraft air influences an area, the larger is the $\mathrm{CO}$ anomaly.

We calculated a time series of CO mass flux at 850,500 , and $300 \mathrm{hPa}$ using the equation

$M=M C \times w \times A \times t$,

where mass $(M)$ is the total amount of $\mathrm{CO}$ transported per time increment, $M C$ is the mass concentration of $\mathrm{CO}, w$ is the vertical velocity, and the time period $(t)$ is $10 \mathrm{~min}$. The mass concentration $M C$ is derived from the volume mixing ratio (VMR) in parts per billion, the standard output from the GCE, using the ideal gas law

$M C=\frac{P_{L} \times M \times C}{R \times T}$

where $P_{L}$ is the pressure level of the mass flux calculation, $M$ is the molecular weight of $\mathrm{CO}, R$ is the universal gas constant, $T$ is temperature, and $C$ is the $\mathrm{CO}$ concentration. The area for the flux calculation ( $A$ in Eq. 2 ) was the width of the grid cell multiplied by $1 \mathrm{~km}$. If the vertical velocity at a level was downward, the concentration above that level was used for the calculation. Conversely if the vertical velocity at the level was upward, the concentration below the level was used.

Time series of CO vertical flux at 300,500 , and $850 \mathrm{hPa}$ are plotted at $10 \mathrm{~min}$ intervals during the 8 -h simulation period (Fig. 11). Summed values over the entire 8-h period for these levels are given in Table 2. One should note the persistent quasi-balance between the upward and downward mass fluxes (Fig. 11). Because the maximum updraft speed at any time step is approximately twice that of the downdraft (Fig. 6a), one might expect that the downward flux would be smaller than the upward flux. However, this is not observed because the area of downdrafts is greater than that of the updrafts, the typical situation in deep convection. Thus, the maximum updraft and downdraft velocity help identify 
Table 2. CO vertical mass flux (t) calculated over 10 min intervals and summed over the entire $8 \mathrm{~h}$ simulation period.

\begin{tabular}{ll}
\hline \multicolumn{2}{l}{ Pressure Level and Calculation } \\
\hline Upward Mass Flux (t) \\
$300 \mathrm{hPa}$ & 96.0 \\
$500 \mathrm{hPa}$ & 129.5 \\
$850 \mathrm{hPa}$ & 33.0 \\
Downward Mass Flux (t) & \\
$300 \mathrm{hPa}$ & 67.1 \\
$500 \mathrm{hPa}$ & 101.9 \\
$850 \mathrm{hPa}$ & 45.6 \\
$\mathrm{Net} \mathrm{Mass} \mathrm{Flux} \mathrm{(t)}$ & \\
$300 \mathrm{hPa}$ & 28.9 \\
$500 \mathrm{hPa}$ & 27.6 \\
$850 \mathrm{hPa}$ & -12.6 \\
\hline
\end{tabular}

the height to which surface $\mathrm{CO}$ can be lofted, but not the quantity of $\mathrm{CO}$ that is transported. The storm maintains a clockwise circulation east of the main updraft which continually circulates $\mathrm{CO}$ away from and toward the surface. We believe that these circulations lead to the enhancement of the upward and downward CO mass flux at $500 \mathrm{hPa}$ (Table 2).

The values of "Net Mass Flux" in Table 2 can be misleading because they are the sum of the upward and downward mass flux at each level. That is, they do not quantify the $\mathrm{CO}$ actually transported away from the surface. For example, the convective transport of $\mathrm{CO}$ out of the boundary layer (below $850 \mathrm{hPa}$ ) is $33.0 t$ over the $8 \mathrm{~h}$ simulation. However, there is net $850 \mathrm{hPa} \mathrm{CO}$ flux toward the surface $(-12.6 t)$. This difference likely is the result of the core updraft developing above the $850 \mathrm{hPa}$ level. Thus, because the downdrafts transport $\mathrm{CO}$ to the surface, they consistently cross the $850 \mathrm{hPa}$ level. It is important to note that the concentration of $\mathrm{CO}$ in the downdraft typically is smaller than the updraft, as seen in the wake of the storm (Fig. 10). Thus, the greater downward mass flux could be a result of circulations ahead of the main updraft transporting greater $\mathrm{CO}$ concentrations toward the surface. Therefore, decreases in $\mathrm{CO}$ in the boundary layer are due to a combination of upward venting and the downward transport of cleaner air.

The change in $\mathrm{CO}$ concentration between storm initiation and the end of the simulation (Fig. 12) summarizes our findings regarding convective transport. The squall line's strong updrafts lead to large $\mathrm{CO}$ increases in the middle and upper troposphere. The ambient winds carry the enhanced $\mathrm{CO}$ downwind of the convection. Upwind of the storm, the rear inflow jet and downdrafts lead to decreases in $\mathrm{CO}$, particularly in the low levels.

Although our simulations were performed using a 2-D model, actual convective transport occurs in three dimensions. It is informative to estimate the amount of $\mathrm{CO}$ that would be transported by a 3-dimensional squall line of the

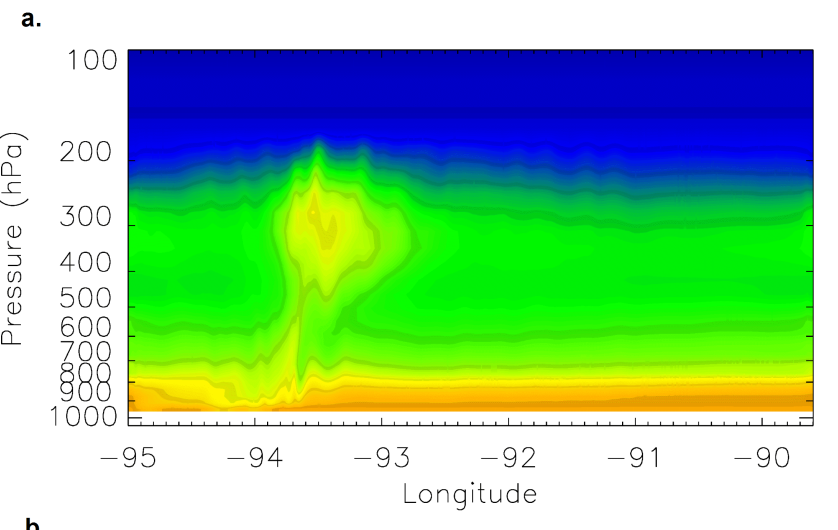

b.
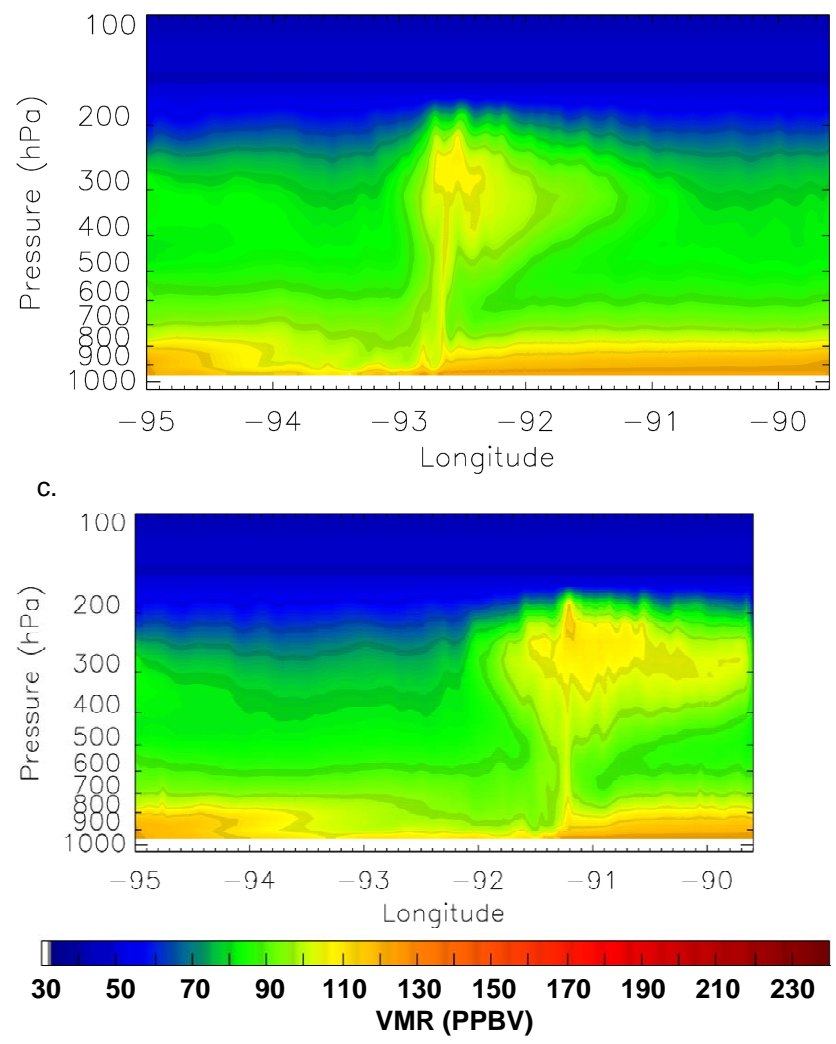

Fig. 10. Simulated CO concentration (ppbv) after (a) $180 \mathrm{~min}$, (b) $310 \mathrm{~min}$, and (c) $480 \mathrm{~min}$.

type described here. We will assume that our initial $\mathrm{CO}$ concentrations (Fig. 4) are uniform along the squall line and that the line is broken, consisting of storms of $30 \mathrm{~km}(\mathrm{~N}-\mathrm{S})$ in size, separated by $15 \mathrm{~km}$, and extending for $450 \mathrm{~km}$ in length. These assumptions produce a transport of $9.9 \times 10^{3} t$ of $\mathrm{CO}$ out of the boundary layer over the $8 \mathrm{~h}$ simulation period, $3.89 \times 10^{4} t$ past $500 \mathrm{hPa}$, and $2.88 \times 10^{4} t$ of $\mathrm{CO}$ above $300 \mathrm{hPa}$ over the $8 \mathrm{~h}$ simulation. Thus, as noted in previous studies (e.g., Cotton et al., 1995; Dickerson et al., 1987), convection truly is a powerful transport mechanism of $\mathrm{CO}$. How well the TES instrument resolves these $\mathrm{CO}$ enhancements is discussed in the next section. 

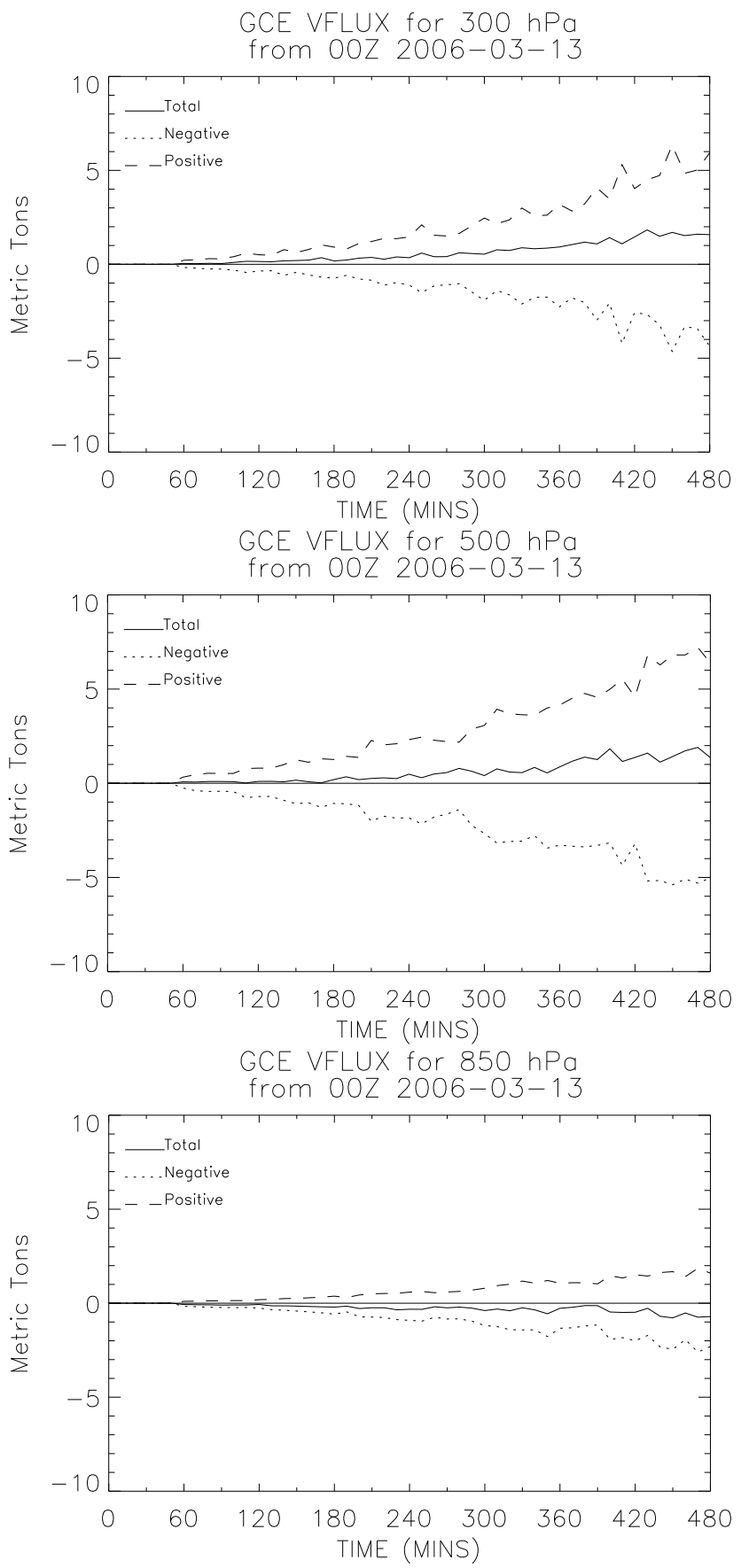

Fig. 11. Time series of vertical CO mass flux (t per $10 \mathrm{~min}$ period) at (a) $300 \mathrm{hPa}$ (b) $500 \mathrm{hPa}$, and (c) $850 \mathrm{hPa}$ during the entire model simulation period.

\subsection{Synthetic CO retrievals}

A major goal of this study is to identify how well the TES instrument resolves the vertical transport of $\mathrm{CO}$ by deep convection. As described earlier, the 2-D GCE model was used to generate atmospheric $\mathrm{CO}$ concentrations during the life of

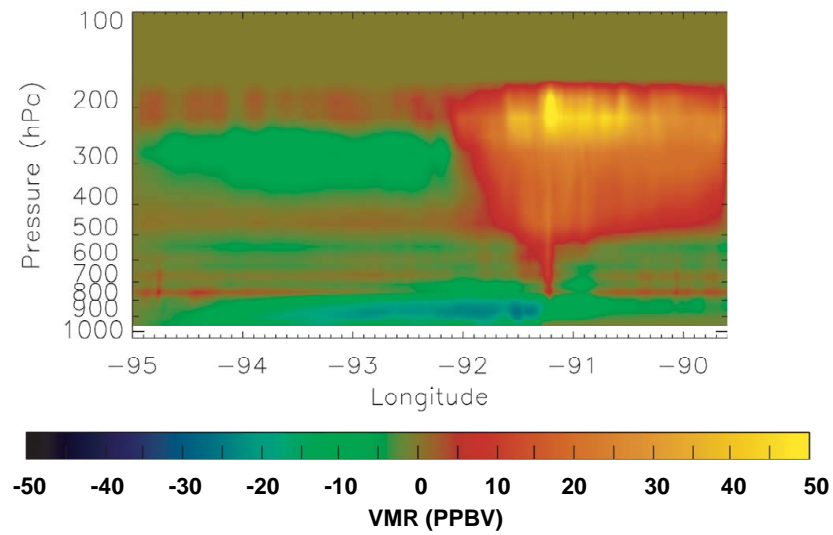

Fig. 12. Change in $\mathrm{CO}$ concentration (ppbv) during the overall $8 \mathrm{~h}$ simulation.

the simulated squall line. Then, by using a clear sky averaging kernel, we retrieved the synthetic $\mathrm{CO}$ concentrations that TES would have seen if it had scanned the region before, during, and after the convection-assuming "transparent clouds". This section presents CO results for the squall line simulation described previously.

We first examine how TES resolved the CO distribution in the pre-squall line environment. The initial CO profile used at all horizontal grid points of the GCE was taken from GEOS-Chem (Fig. 4). The profile was located in a cloudfree region of the pre-squall line environment at $41.61^{\circ} \mathrm{N}$, $90.58^{\circ} \mathrm{W}$ at 00:00 UTC 13 March 2006 during the INTEXB mission (Singh et al., 2009). However, by 08:15 UTC 13 March (Fig. 2) a well developed squall line stretched through this area. We chose the averaging kernel profile at a cloud-free location (from scan 14 of the Level 2 TES file for RUNID 3443 on 13 March) for all of the synthetic retrieval locations because its pre-storm thermodynamic profile was most similar to that used in our GCE model run (Fig. 3). Using the same averaging kernel profile at every location means that atmospheric thermodynamics will not be a factor in causing retrieval differences (Luo et al.,2007a).

A brief explanation of the averaging kernel is useful at this time. The diagonal of the averaging kernel describes the fractional contribution of the true concentration of the species at the pressure level, relative to the sum of all elements of the averaging kernel. The magnitude of the averaging kernel diagonal depends on the number of pressure levels that the satellite retrieves, and therefore is unique to the retrieval. A TES CO averaging kernel diagonal containing the greatest information has a value of $\sim 0.1$ (S. Kulawik, personal communication, 2007). The diagonal profile values (Fig. 13) were available in the level 2 data product supplied by the TES science team (TES L2 Data User's Guide, 2006). The averaging kernel diagonal that we used for all points in the model domain has values $\sim 0.1$ only between $\sim 650$ and $\sim 380 \mathrm{hPa}$. Therefore, this layer has the greatest sensitivity to our initial 


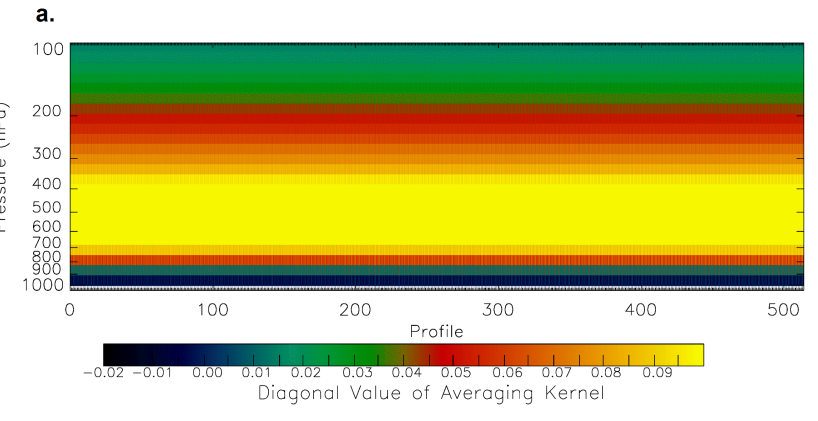

Fig. 13. Clear sky averaging kernel diagonal used in the TES retrievals from profile 14 of RUNID 3443 on 13 March 2006 (see location in Fig. 2a) that was applied to all horizontal grid points in the 2-D GCE model domain

and convectively modified CO concentrations. Diagonal values decrease sharply below this layer and more gradually above, reaching values as small as $\sim 0.01$. As noted earlier, the same averaging kernel was used at all locations along the cross section.

Magnitudes of the synthetic TES retrievals for the initial $\mathrm{CO}$ field (Fig. 14b) differ from those of the input GEOSChem data (Fig. 14a); however, patterns of the initial and retrieved fields are similar. Some of the greatest differences are located near the surface, where the TES- retrieved CO is $\sim 30 \mathrm{ppb}$ greater than the GEOS-Chem input. Concentrations in the middle troposphere are similar to the original, while TES values are somewhat greater than the initial values near $200 \mathrm{hPa}$. Slight differences between the vertical temperature profile of the "clear sky" TES retrieval and that used in the GCE modeling are a possible explanation for differences between the GEOS-Chem CO profile and the synthetic TES CO retrieval. Since we used the same averaging kernel and a priori profile at every grid point, we must interpret the synthetic TES retrievals of the convectively altered CO field (hereafter $\mathrm{CCO})$ by considering this initial difference.

We next present the synthetic TES CO retrievals for the simulated squall line (Fig. 15). We have superimposed the storm's cloudy region on the cross section to identify areas where clouds would prevent "clear-sky" retrievals from being reliable in the "real world". Specifically, any region beneath the cloudy area would not be properly sensed by a TES instrument in actual orbit; however, all regions above the cloudy scene reflect the sensitivity of the "clear-sky" averaging kernel. Figure 15 shows synthetic TES retrievals for the GCE modeled storm cross section at a) $180 \mathrm{~min}$, b) $300 \mathrm{~min}$, and c) $480 \mathrm{~min}$ into the simulated storm.

Comparing Figs. 10 and 15 reveals that TES resolves the general pattern of the $\mathrm{CCO}$ field. The plume is detected at heights nearly identical to those from the GCE, even in the cloudy area since we assumed a "clear-sky" averaging kernel (Fig. 13). At 300 and $480 \mathrm{~min}$ (Fig. 15b-c) respectively, relatively small $\mathrm{CO}$ concentrations are located upwind (left)

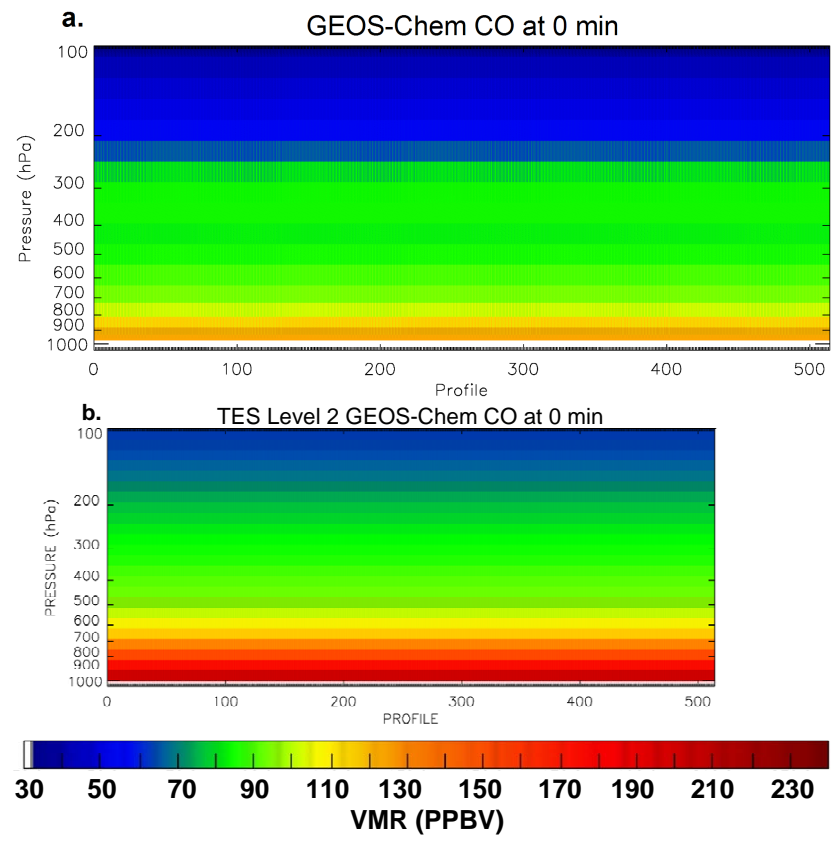

Fig. 14. (a) Initial CO concentration (ppbv) used in the GCE simulation, (b) Synthetic TES retrievals of the initial CO concentration (ppbv).

of the storm in the upper levels, but enhanced values are produced above the cloud. The synthetic TES retrievals also reveal the large concentrations of $\mathrm{CO}$ within the storm's updraft in this "clear-sky" situation. In the "real world" this region would be enshrouded by deep cumulonimbus clouds that would prevent TES from adequately sensing the area. However, due to the strong updraft-induced lofting of $\mathrm{CO}$ deep into the troposphere and lower stratosphere where environmental winds are relatively strong, much of the lofted $\mathrm{CO}$ will be transported above the storm and downwind of the cloudy region. Thus, $\mathrm{CO}$ enhancements sensed above deep convection likely signify even larger $\mathrm{CO}$ enhancements below that level when the shape of the averaging kernel profile is similar to the one applied in our retrievals.

This hypothesis is explored further using Fig. 16 which shows differences (ppbv) between the initial synthetic TES retrievals and those of the $\mathrm{CCO}$ field. The increased $\mathrm{CO}$ above the storm system can be explained by the structure of the averaging kernels, best shown by its diagonal. The averaging kernel in our case obtains most of its information about the atmosphere's true state (GCE output) in the middle levels (Fig. 13). And, this is the layer where greatest $\mathrm{CO}$ concentrations are located (Fig. 10). The large values retrieved in the middle levels influence the TES retrievals above and below the layer to which TES is most sensitive. Thus, CCO enhancements within and above the storm are too great, since the GCE produced smaller CO increases. Thus in the "real world", the interpretation of TES data must 


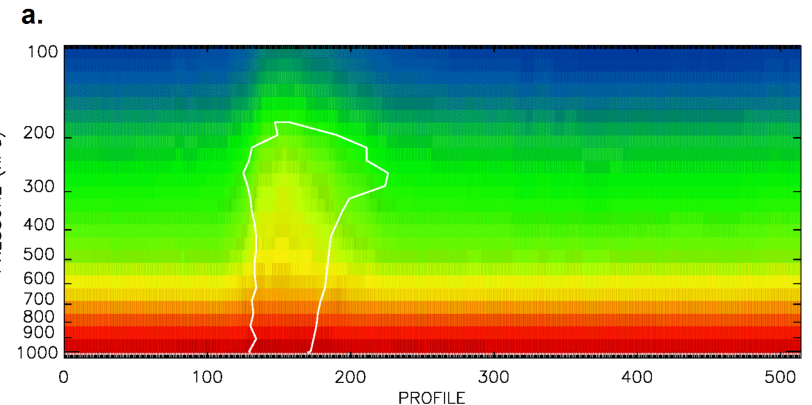

b.
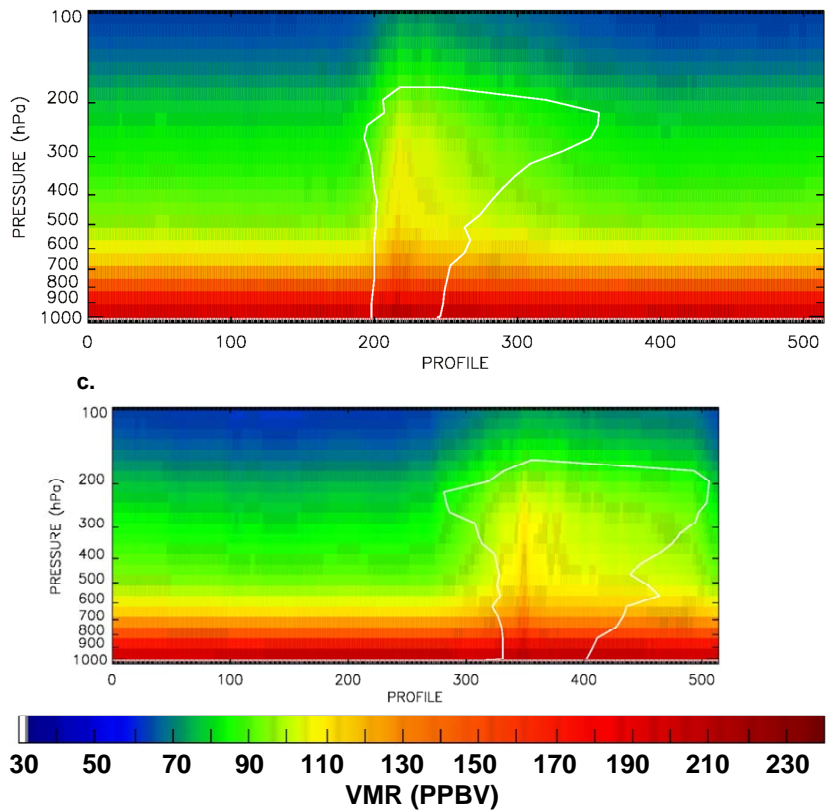

Fig. 15. Synthetic TES retrievals (ppbv) at (a) $180 \mathrm{~min}$, (b) $300 \mathrm{~min}$, and (c) $480 \mathrm{~min}$. The white outline in the figure is the region of clouds associated with the storm system. TES retrievals in regions below and within this area are interpereted as being unrealible because of the "clear-sky" averaging kernel used for the profiles.

consider the averaging kernel diagonal in the area of study. That sensitivity information enables one to speculate about the concentration in the lower and middle troposphere based on enhanced $\mathrm{CO}$ in the upper levels of the retrieval.

A somewhat surprising feature in Fig. 16 is the reduction in detected $\mathrm{CO}$ concentrations near the surface in the wake (left) of the storm system. Although the magnitude of this reduction is $\sim 15 \mathrm{ppbv}$ (compared with $\sim 30 \mathrm{ppbv}$ from the GCE model) (Figs. 10c and 16c), the general area of diminished CO is correctly depicted.

MCSs by definition are associated with deep clouds that usually spread out ahead of and behind the storm system in the upper levels. These clouds are the major reason why the averaging kernel diagonal is not $\sim 0.1$ but much smaller, i.e., the clouds are not handled adequately by the TES retrieval algorithm. Fortunately, however, winds in the upper levels

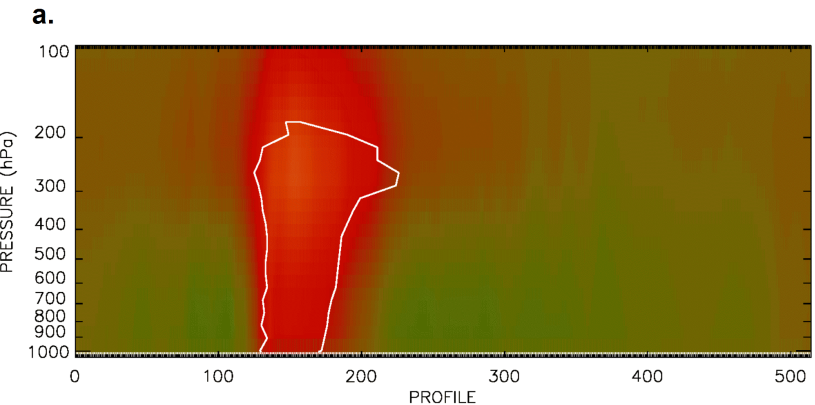

$$
\text { b. }
$$
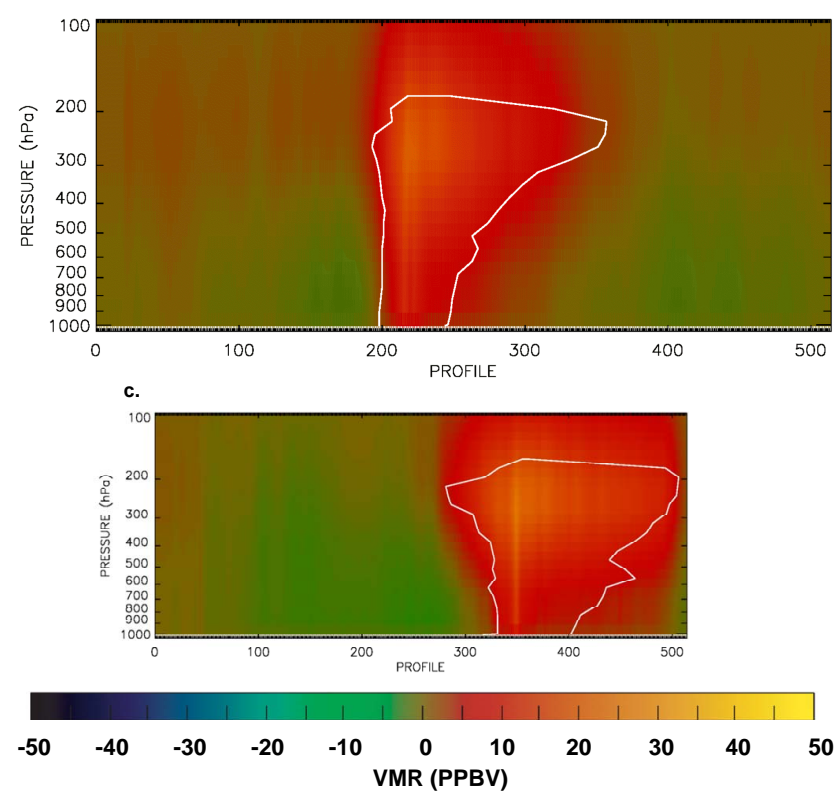

Fig. 16. Plots of the difference (ppbv) between synthetic TES CO retrievals and the initial CO concentration (as seen by TES) at (a) $180 \mathrm{~min}$, (b) $300 \mathrm{~min}$, and (c) $480 \mathrm{~min}$. The white outline is the region of the storms clouds, as in Fig. 15.

of the MCS environment typically are strong enough to carry lofted pollution away from the cloudy region. Therefore, the best way to infer lofted pollution using the TES instrument is to look downwind of the system after the storm has been organized for several hours.

\subsection{Observed TES CO retrievals}

As a final point, we investigate actual TES retrievals for the squall line occurring at 08:04 UTC 13 March 2006 during INTEX-B - the case whose CO profile and averaging kernel were used in the earlier simulations. Unfortunately, no INTEX-B aircraft were optimally downwind of this squall line or any other during the mission. Thus, no in situ data are available for the event. The TES swath intersects the squall line over northern Illinois (Fig. 2a), and the locations of missing profiles are immediately apparent (Figs. 2a and 17). These profiles are skipped because multiple cloud layers or 

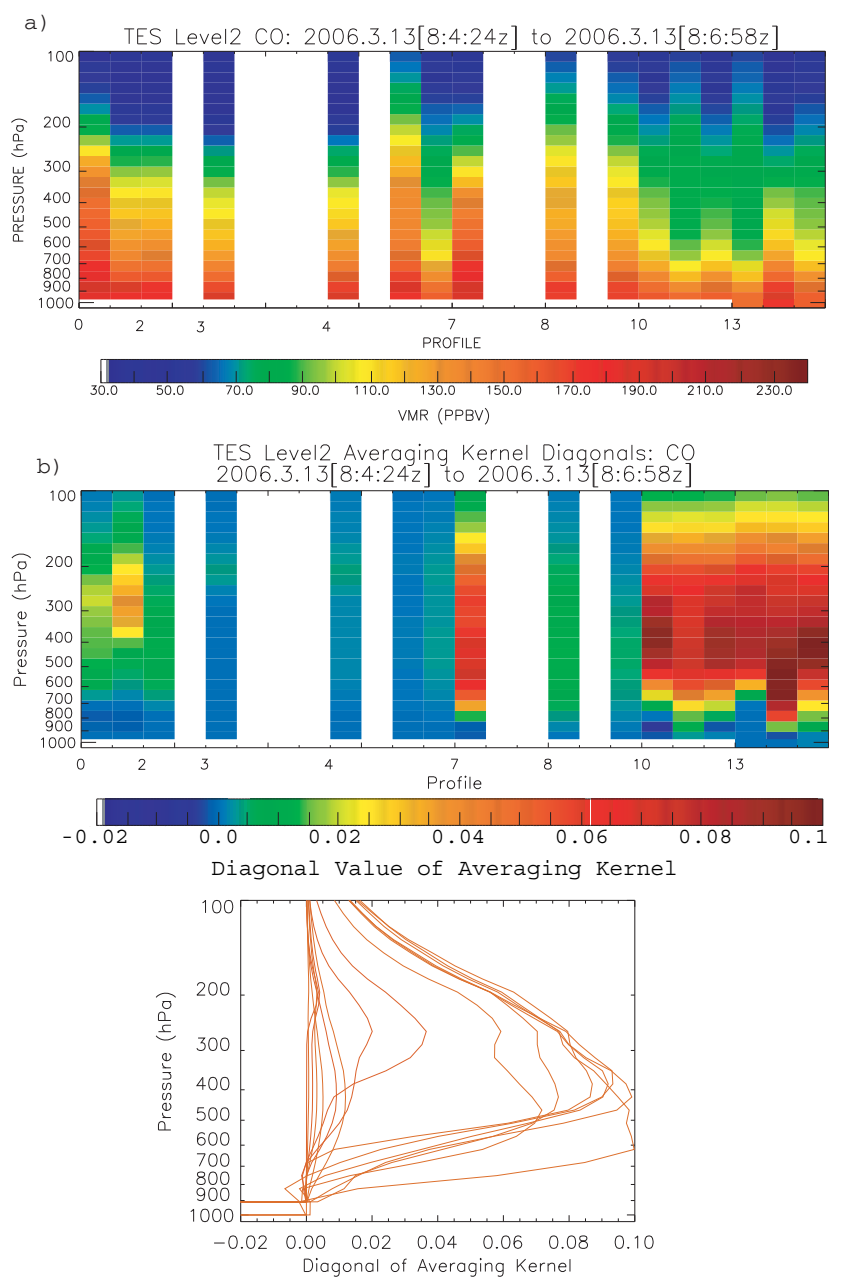

with an overall shape that is similar to that used in our synthetic TES retrievals (Fig. 13). TES profile 7 exhibits a vertical distribution of $\mathrm{CO}$ that is similar to the pattern found in the synthetic retrievals (Fig. 15), indicating the effects of convective transport. When analyzing profile 7 , the reader is reminded that the TES algorithm enhances true CO concentrations near the surface as was seen in the synthetic profiles (Fig. 14). One also should note that GEOS-Chem produced surface $\mathrm{CO}$ values of $\sim 130 \mathrm{ppbv}$ in this area, which is $\sim 40 \mathrm{ppbv}$ less than the TES-retrieved concentration at this same location (not shown). Retrieval 10 (Fig. 17) also contains significant valid information, with the greatest portion coming from the upper levels of the atmosphere. This suggests that the convective impact may be minimal at this retrieval. This retrieval is located over southeastern Missouri, farther downwind of the squall line than retrieval 7 , and the upper level $\mathrm{CO}$ outflow may not yet have reached this location. One should note that the same a priori profile was used to create all of the retrievals, including profiles 7 and 10. This ensures that differences between these retrievals are not due to spatial patterns in the a priori.

The SS TES retrievals that we examined above were separated by $\sim 45 \mathrm{~km}$, and each footprint was $\sim 5 \times 8 \mathrm{~km}$ (Sect. 2.1). We can only provide a qualitative discussion as to the limiting factor for TES to detect storm induced CO uplift. TES will miss convection in a small area that is smaller than $45 \mathrm{~km}$. And, weak convection will not transport much CO to the upper troposphere, meaning that TES probably will not detect the event. However, Figs. 15 and 16 show that TES should be able to retrieve the differently shaped CO profiles (compared to the background) that are associated with major areas of convection, such as the squall line investigated here.

To summarize, we stress that TES retrievals by themselves

Fig. 17. (a) Observed TES CO retrievals (ppbv) for RUNID 3443 at 08:04 UTC 13 March 2006 for profiles 0-15, (b) TES averaging kernel diagonals for RUNID 3443 and profiles 0-15. Profiles 0 (15) are the northern most (southern most) sites in Fig. 2a.

the deep convection cause the retrieval scheme to determine that there is insufficient scene information. One should note that some of the profiles that were retained near the squall line exhibit very small values of the averaging kernel diagonal (Fig. 17b). Thus, in spite of their presence, they contain little information about the true atmospheric state. For example, retrievals 0 and 5 appear to show enhanced values throughout the vertical column (Fig. 17a). However, their averaging kernel diagonals (Fig. 17b) indicate that the enhancement actually is false because the diagonal values are near zero at all levels.

Retrieval 7 (Fig. 17a) is the first in the swath to include significant information about the true state of the atmosphere. It is located $\sim 60 \mathrm{~km}$ downwind of the leading edge of the squall line (Fig. 2a) in south central Illinois. Its kernel diagonal (Fig. 17b) has a peak of $\sim 0.08$ in the mid-troposphere, can be misleading especially in regions of cumulonimbus clouds. However, knowledge of profile sensitivities at each level can lead to better understanding and use of TES retrievals in both the model domain and real atmosphere.

\section{Conclusions}

This study has quantified the vertical transport of lower tropospheric carbon monoxide (CO) by deep convection associated with mesoscale convective systems. Specifically, a squall line was simulated based on a typical environmental wind shear profile using the 2-D Goddard Cumulus Ensemble model. The wind profile had a varying shear of $17 \mathrm{~m} \mathrm{~s}^{-1}$ over a $9 \mathrm{~km}$ depth. The simulation provided post-convection $\mathrm{CO}$ profiles. The ability of the TES instrument to resolve the convectively modified CO distributions then was analyzed using a "clear-sky" retrieval methodology. Results showed that the squall line transported a large mass of $\mathrm{CO}$ into the upper levels, specifically $96 t$ upward and $67 t$ downward at $300 \mathrm{hPa}$. 
We conclude that TES is able to detect convectively transported $\mathrm{CO}$ as seen both in synthetic retrievals based on convective modeled output and from an actual convective event. However, we stress that this can be accomplished only with the aid of the averaging kernels that are supplied with the Level 2 data files. The kernel diagonals describe the sensitivity of the $\mathrm{CO}$ retrieval at different pressure levels. Cloud cover associated with convection poses a major problem for TES to detect the associated vertical transport. However, TES swaths that are located immediately downwind of squall lines were found to have the greatest chance of detecting convective transport because these locations have less cloud cover, and the impact of clouds on retrieval quality becomes less of an issue. The stronger middle and upper level winds that are associated with intense convection will advect the $\mathrm{CO}$ downwind and beyond the cloudy area. $\mathrm{CO}$ enhancements above the storm's cloud tops were sensed by TES retrievals using $\mathrm{CO}$ profiles from a cloud model simulation as the true atmospheric state. However, since the major storminduced $\mathrm{CO}$ enhancements occur in the upper levels, the retrieval algorithm tends to smear this enhancement above and below its altitude. Thus, a note of caution is to always analyze TES-derived CO data (or data from any satellite sensor) together with the retrieval averaging kernels that describe the information content of the retrieval. Since the retrieved values can be misleading, information about the sensitivity of the retrieval allows one to selectively use the data in analyses and studies of pollution transport.

Improved horizontal retrieval coverage would provide more opportunities to capture convective transport events, and MOPITT CO measurements probably are better in this regard. Although TES and MOPITT have similar vertical resolutions, MOPITT has much better horizontal coverage even though its nadir footprint is $\sim 22 \times 22 \mathrm{~km}$. Conversely, the vertical resolution of AIRS is slightly worse than TES and MOPITT. The new IASI (Infrared Atmospheric Sounding Interferometer, Chalon et al., 2008) instrument has a $12 \mathrm{~km}$ nadir footprint that has great potential for many future applications. An advantage of TES is its co-located measurements of $\mathrm{CO}$ and $\mathrm{O}_{3}$, not $\mathrm{CO}$ alone. Finally, polar orbiting satellites do not continuously scan the same location, e.g., an area of convection. Therefore, sensors in geostationary orbit would be ideal for monitoring convective outflow and many other phenomena.

Acknowledgements. We appreciate the helpful advice of Annmarie Eldering and Greg Osterman at JPL. We also thank Wei-Kuo Tao of NASA/GSFC for use of the GCE model. This research was sponsored by NASA's Tropospheric Chemistry Program under grant NNG06B43G to Florida State University.

Edited by: H. Singh

\section{References}

Beer, R.: TES on the Aura Mission: Scientific Objectives, Measurements, and Analysis Overview, IEEE T. Geosci. Rem. Sens., 44, 1102-1105, 2006.

Bey, I., Aumont, B., and Toupance, G.: A modeling study of the nighttime radical chemistry in the lower continental troposphere: 1. Development of a detailed chemical mechanism including nighttime chemistry, J. Geophys. Res., 106, 9959-9990, 2001 a.

Bey, I., Jacob, D. J., Yantosca, R. M., Logan, J. A., Field, B. D., Fiore, A. M., Li, Q., Liu, H., Mickley, L. J., and Schultz, M. G.: Global modeling of tropospheric chemistry with assimilated meteorology: Model description and evaluation, J. Geophys. Res., 106, 23073-23089, 2001b.

Bloom, S., da Silva, A., Dee, D., Bosilovich, M., Chern, J.-D., Pawson, S., Schubert, S., Sienkiewicz, M., Stajner, I., Tan, W.-W., and $\mathrm{Wu}$, M.-L.: Documentation and Validation of the Goddard Earth Observing System (GEOS) Data Assimilation System Version 4, Technical Report Series on Global Modeling and Data Assimilation 104606, 26, 2005.

Bluestein, H. B. and Jain, M. H.: Formation of mesoscale lines of precipitation: Severe squall lines in Oklahoma during the spring, J. Atmos. Sci., 42, 1711-1732, 1985.

Bowman, K. W., Rodgers, C. D., Kulawik, S. S., et al.: Tropospheric emission spectrometer: Retrieval method and error analysis, IEEE T. Geosci. Rem. Sens., 44, 1297-1307, 2006.

Chalon, G., Cayla, F., and Diebel, D.: IASI: An advanced sounder for operational meteorology, Proceedings of the 52nd Congress of IAF, Toulouse France, 1-5 October 2001.

Chatfield, R. B. and Delany, A. C.: Convection links biomass burning to increased tropical ozone: However, models will tend to over predict $\mathrm{O}_{3}$, J. Geophys. Res., 95, 18473-18488, 1990.

Cotton, W. R., Alexander, G. D., Hertenstein, R., Walko, R. L., McAnelly, R. L., and Nicholls, M.: Cloud venting-A review and some new global annual estimates, Earth-Sci. Rev., 39, 169-206, 1995.

Dickerson, R. R., Huffman, G. J., Luke, W. T., Nunnermacker, L. J., Pickering, K. E., Leslie, A. C. D., Lindsey, C. G., Slinn, W. G. N., Kelly, T. J., Daum, P. H., Delany, A. C., Greenberg, J. P., Zimmerman, P. R., Boatman, J. F., Ray, J. D., and Stedman, D. H.: Thunderstorms: An important mechanism in the transport of pollutants, Science, 237, 460-465, 1987.

Dickerson, R. R., Li, C., Li, Z., Marufu, L. T., Stehr, J. W., Chen, H., Wang, P., Xia, X., Ban, X., Gong, F., Yuan, J., and Yan, J.: Aircraft observations of dust and pollutants over N. E. China: Insight into the meteorological mechanisms of long range transport, J. Geophys. Res., 112, D24S90, doi:10.1029/2007JD008999, 2007.

Drummond, J. R., and Mand, G. S.: The measurements of pollution in the troposphere (MOPITT) instrument: Overall performance and calibration requirements. J. Atmos. Ocean. Technol., 13, 314-320, 1996.

Duncan, B. N., Martin, R. V., Staudt, A. C., Yevich, R., and Logan, J. A.: Interannual and seasonal variability of biomass burning emissions constrained by satellite observations, J. Geophys. Res., 108, 4100, doi:10.1029/2002JD002378, 2003.

Fovell, R. G. and Ogura, Y.: Numerical simulation of a midlatitude squall line in two dimensions, J. Atmos. Sci., 45, 1988.

GEOS-Chem User's Guide, Vers. 7.03.06: 8 November 2005 , Atmos. Chem. Modeling Group, Harvard University, http: 
//www-as.harvard.edu/chemistry/trop/geos/doc/man/index.html, 25 April 2007.

Glickman, T. S. (ed.): Glossary of Meteorology, 2nd ed., Boston, Massachusetts, USA, American Meteorological Society, 2000.

Hack, J. J.: Parameterization of moist convection in the National Center for Atmospheric Research Community Climate Model (CCM2), J. Geophys. Res., 99, 5551-5568, 1994.

Hannan, J. R., Fuelberg, H. E., Crawford, J. H., Sachse, G. W., and Blake, D. R.: Role of wave cyclones in transporting boundary layer air to the free troposphere during the spring 2001 NASA/TRACE-P experiment, J. Geophys. Res., 108, doi:10.1029/2002JD003105, 2003.

Isaac, G. A., Joe, P. I., and Summers, P. W.: The vertical transport and redistribution of pollutants by clouds, Specialty Conf. on the Meteorology of Acid Deposition, October 1983, edited by: Samson, P. J., Pittsburg, PA, USA, Air Pollution Control Association, 496-512, 1983

Jacob, D. J.: Introduction to Atmospheric Chemistry, Princeton, New Jersey, USA, Princeton University Press, 1999.

Kiley, C. M. and Fuelberg, H. E.: An examination of summertime cyclone transport processes during Intercontinental Chemical Transport Experiment (INTEX-A), J. Geophys. Res., doi:10.1029/ 2006JD007115, 2006.

Klemp, J. B. and Wilhelmson, R. B.: The simulation of threedimensional convective storm dynamics, J. Atmos. Sci., 35, 1070-1096, 1978.

Kulawik S. S., Worden, H., Osterman, G., Luo, M., Beer, R., Kinnison, D. E., Bowman, K. W., Worden, J., Eldering, A., Lampel, M., Steck, T., and Rodgers, C. D.: TES atmospheric profile retrieval characterization: An orbit of simulated observations, IEEE T. Geosci. Rem. Sens., 44, 1324-1333, 2006.

Lericos, T. P., Fuelberg, H. E., Weisman, M. L., and Watson, A. I.: Numerical simulations of the effects of coastlines on the evolution of strong, long-lived squall lines, Mon. Weather Rev., 135, 1710-1731, 2006.

Lin, Y.-L., Farley, R. D., and Orville, H. D.: Bulk parameterization of the snow field in a cloud model, J. Appl. Meteor., 22, 10651092, 1983.

Lobert, J. M., Keene, W. C., Logan, J. A., and Yevich, R.: Global chlorine emissions from biomass burning: The reactive chlorine emissions inventory, J. Geophys. Res., 104, 8373-8390, 1999.

Lopez, J. P., Luo, M., Christensen, L. E., Loewenstein, M., Jost, H., Webster, C. R., and Osterman, G.: TES carbon monoxide validation during two AVE campaigns using the Argus and ALIAS instruments on NASA's WB-57F, J. Geophys. Res., 113, D16S47, doi:10.1029/2007JD008811, 2008

Luo, M., Beer, R., Jacob, D. J., Logan, J. A., and Rogers, C. D.: Simulated observation of tropospheric ozone and $\mathrm{CO}$ with the Tropospheric Emission Spectrometer (TES) satellite instrument, J. Geophys. Res., 107, doi:10.1029/2001JD000804, 2002.

Luo, M., Rinsland, C. P., Rodgers, C. D., Logan, J. A., Worden, H., Kulawik, S., Eldering, A., Goldman, A., Shephard, M. W., Gunson, M., and Lampel, M.: Comparison of carbon monoxide measurements by TES and MOPITT: Influence of a priori data and instrument characteristics on nadir atmospheric species retrievals, J. Geophys. Res., 112, D09303, doi:10.1029/2006JD007663, 2007a.

Luo, M., Rinsland, C., Fisher, B., et al.: TES carbon monoxide validation with DACOM aircraft measurements during INTEX-B 2006, J. Geophys. Res., 112, D24S48, doi:10.1029/2006JD007663, 2007b.

Luo, M., Worden, H., and TES team: Steps of making comparisons of TES nadir retrievals to your profiles with higher vertical resolution, <http://tes.jpl.nasa.gov/temp/Web_help/web.html> NASA Facts On Line: "Measurement of Air Pollution from Satellites (MAPS) - understanding the chemistry of the atmosphere", http://oea.larc.nasa.gov/PAIS/MAPS.html (last access: 3 May 2007), 19 September 1996.

Niewiadomski, M.: A passive pollutant in a three-dimensional field of convective clouds: Numerical simulations, Atmos. Environ., 20, 139-=-145, 1986.

Ogura, Y. and Liou, M.: The structure of a midlatitude squall line: A case study, J. Atmos. Sci., 37, 553-567, 1980.

Park, R. J., Stenchikov, G. L., Pickering, K. E., Dickerson, R. R., Allen, D. J., and Kondragunta, S.: Regional air pollution and its radiative forcing: Studies with a single-column chemical and radiation transport model, J. Geophys. Res., 106, 28751-28770, 2001.

Pickering, K. E., Dickerson, R. R., Luke, W. T., and Nunermacker, L. J.: Clear sky vertical profiles of trace gases as influenced by upstream convective activity, J. Geophys. Res., 94, 14879$14892,1989$.

Pickering, K. E., Thompson, A. M., Dickerson, R. R., Luke, W. T., McNamara, D. P., Greenberg, J. P., and Zimmerman, P. R.: Model calculations of tropospheric ozone production potential following observed convective events, J. Geophys. Res., 95, 14049-14062, 1990.

Pickering, J. E., Thompson, A. M., Scala, J. R., Tao, W.-K., Simpson, J., and Garstang, M.: Photochemical ozone production in tropical squall line convection during NASA/GTE/ABLE 2A, J. Geophys. Res., 96, 3099-3114, 1991.

Pickering, J. E., Thompson, A. M., Scala, J. R., Tao, W.-K., and Simpson, J.: Ozone production potential following convective redistribution of biomass emissions, J. Atmos. Chem., 14, $297-$ 313, 1992a.

Pickering, J. E., Scala, J., Thompson, A. M., Tao, W.-K., and Simpson, J.: A regional estimate of convective transport of CO from biomass burning, Geophys. Res. Lett., 19, 289-292, 1992b.

Pickering, J. E., Thompson, A. M., Scala, J. R., Tao, W.-K., Dickerson, R. R., and Simpson, J.: Free tropospheric ozone production following entrainment of urban plumes into deep convection, J. Geophys. Res., 97, 17985-18000, 1992c.

Pickering, K. E.: Convective Transport, Handbook of Weather, Climate and Water: Atmosphere Chemistry, Hydrology, and Societal Impacts, edited by: Potter, T. D. and Colman, B. R., Wiley Interscience, Hoboken, NJ, USA, 157-177, 2003.

Pickering, J. E., Thompson, A. M., Tao, W., Rood, R. B., McNamara, D. P., and Molod, A. M.: Vertical transport by convective clouds: Comparisons of three modeling approaches, Geophys. Res. Lett., 22, 1089-1092, 1995.

Rodgers, C. D.: Inverse Methods for Atmospheric Sounding, Theory and Practice, Hackensack, New Jersey, USA, World Scientific Publishing Co., 256 pp., 2000.

Rodgers, C. D. and Connor, B. J.: Intercomparison of remote sounding instruments, J. Geophys., Res., 108, 4116, doi:10.1029/2002JD002299, 2003.

Rotunno, R., Klemp, J. B., Weisman, M. L.: A theory for strong, long-lived squall lines, J. Atmos. Sci., 45, 463-485, 1987. 
Scala, J., Garstang, M., Tao, W.-K., Pickering, K., Thompson, A., Simpson, J., Kirchhoff, V., Browell, E., Sachse, G., Torres, A., Gregory, G., Rasmussen, R., and Khalil, M.: Cloud draft structure and trace gas transport, J. Geophys. Res., 95, 17015-17030, 1990.

Singh, H. B., Brune, W. H., Crawford, J. H., Jacob, D. J., and Russell, P. B.: Overview of the summer 2004 Intercontinental Chemical Transport Experiment-North America (INTEX-A), J. Geophys. Res., 111, D24S01, doi:10.1029/2006JD007905, 2006.

Singh, H. B., Brune, W. H., Crawford, J. H., Flocke, F., and Jacob, D. J.: Chemistry and transport of pollution over the Gulf of Mexico and the Pacific: spring 2006 INTEX-B campaign overview and first results, Atmos. Chem. Phys., 9, 2301-2318, 2009, http://www.atmos-chem-phys.net/9/2301/2009/.

Soong, S.-T. and Ogura, Y.: Response of trade wind cumuli to largescale processes, J. Atmos. Sci., 37, 2035-2050, 1980.

Soong, S.-T. and Tao, W.-K.: Response of deep tropical clouds to mesoscale processes, J. Atmos. Sci., 37, 2016-2036, 1980.

Stenchikov, G., Dickerson, R., Pickering, K., Ellis, W., Doddridge, B., Kondragunta, S., Poulida, O., Scala, J., and Tao, W.-K.: Stratosphere-troposphere exchange in a mid-latitude mesoscale convective complex: Part 2, Numerical simulations, J. Geophys. Res., 101, 6837-6851, 1996.

Tao, W.-K. and Simpson, J.: Cloud interactions and merging: Numerical simulations, J. Atmos. Sci., 41, 2901-2917, 1984.

Tao, W.-K. and Simpson, J.: Goddard cumulus ensemble model. Part 1: Model description, Terr. Atmos. Oceanic Sci., 4, 35-72, 1993.

Tao, W.-K., Simpson, J., Baker, D., Braun, S., Chou, M.-D., Ferrier, B., Johnson, D., Khain, A., Lang, S., Lynn, B., Shie, C.-L., Starr, D., Sui, C.-H., Wang, Y., and Wetzel, P.: Microphysics, radiation and surface processes in the Goddard Cumulus Ensemble (GCE) model, Meteorol. Atmos. Phys., 82, 97-137, 2003.

Tao, W.-K., Simpson, J., and Soong, S.-T.: Numerical simulation of a subtropical squall line over the Taiwan Strait, Mon. Weather Rev., 119, 2699-2723, 1991.

Tao, W.-K. and Soong, S.-T.: A study of the response of deep tropical clouds to mesoscale processes: Three-dimensional model experiments, J. Atmos. Sci., 43, 2653-2676, 1986.

Osterman, G. (ed.): TES L2 Data User's Guide. Vers. 1.00. 11 Apr. 2006. Jet Propulsion Laboratory, California Institute of Technology. June 2006, http://tes.jpl.nasa.gov/docsLinks/ DOCUMENTS/TESL2DataUsersGuidev2.0.pdf
Thompson, A. M., Pickering, K. E., Dickerson, R. R., Ellis Jr., W. G., Jacob, D. J., Scala, J. R., Tao, W.-K., McNamara, D. P., and Simpson, J.: Convective transport over the central United States and its role in regional CO and ozone budgets, J. Geophys. Res., 99, 18703-18712, 1994.

Thompson, A. M., Tao, W. K., Pickering, K. E., Scala, J. R., and Simpson, J.: Tropical deep convection and ozone formation, B. Am. Meteor. Soc., 78, 1043-1054, 1997.

Thorpe, A. J., Miller, M. J., and Moncrieff, M. W.: Twodimensional convection in non-constant shear: a model of midlatitude squall lines, Q. J. Roy. Met. Soc., 108, 739-762, 1982.

Tremblay, A. and Leighton, H.: A three-dimensional cloud chemistry model, J. Clim. Appl. Meteorol., 25, 652-671, 1986.

Wang, Y., Jacob, D. J., and Logan, J. A.: Global simulation of tropospheric O3-NO $-\mathrm{NO}_{\mathrm{X}}$-hydrocarbon chemistry: 1. Model formulation, J. Geophys. Res., 103, 10713-10725, 1998a.

Warning Decision Support System - Integrated Information. NOAA/National Severe Storms Laboratory, University of Oklahoma, USA, online available at: http://www.wdssii.org/, 23 June 2007.

Weisman, M. L. and Klemp, J. B.: The dependence of numerically simulated convective storms on wind shear and buoyancy, Mon. Weather Rev., 110, 504-520, 1982.

Weisman, M. L. and Klemp, J. B.: The structure and classification of numerically simulated con-vective storms in directionally varying wind shear, Mon. Weather Rev., 112, 2479-2498, 1984.

Weisman, M. L., Klemp, J. B., and Rotunno, R.: Structure and evolution of numerically simulated squall lines, J. Atmos. Sci., 45, 1990-2013, 1988.

Weisman, M. L. and Rotunno, R.: A theory for strong long-lived squall lines revisited, J. Atmos. Sci., 61, 361-382, 2004.

Zhang, G. J. and McFarlane, N. A.: Sensitivity of climate simulations to the parameterization of cumulus convection in the Canadian Climate Centre general circulation model, Atmos. Ocean, 33, 407-446, 1995.

Zhang, Q., Streets, D. G., Carmichael, G. R., He, K., Huo, H., Kannari, A., Klimont, Z., Park, I., Reddy, S., Fu, J. S., Chen, D., Duann, L., Lei, Y., Wang, L., and Yao, Z.: Asian emissions in 2006 for the NASA INTEX-B mission, Atmos. Chem. Phys. Discuss., 9, 4081-4139, 2009, http://www.atmos-chem-phys-discuss.net/9/4081/2009/. 